\title{
ライフスタイルと健康
}

\author{
森 本 兼 粪
}

大阪大学大学院医学系研究科社会環境医学講座

\author{
Lifestyle and Health
}

Kanehisa MORIMOTO

Department of Social and Environmental Medicine, Osaka University Graduate School of Medicine, Osaka

\begin{abstract}
The total environments to which individuals have been exposed throughout the lifestages from birth to the present time have been composing the individual and community lifestyles. Such lifestyles are known to determine the risks for developments of cancers, circulatory diseases, and other chronic diseases.

To establish new theory and practice programs for disease prevention and health promotion in the environmental and preventive medicine, we have quantitatively investigated correlations of lifestyles, or ways of daily living, to comprehensive health potentials in the cohort of industrial workers. The total lifestyles were evaluated by the originally-designed 8 health-practices such as smoking, alcohol-drinking, physical exercise, and working and sleeping patterns. The data indicate that individuals having good lifestyles showed much younger health ages calculated based on the health-check-up data, and lower risks for developing lifestyle-related diseases than those with poor lifestyles.

The physical health potentials were assessed by the biomarker-measurements such as lymphocyte chromosome-DNA alterations, natural-killer activities and serum IgE levels. The psycho-mental health potentials were evaluated by both the quality-of-life-related questionnaires and the stress-related hormonal and cytokine levels such as cortisol and interleukines. The comprehensive health potentials have been shown to be significantly lower in poor-lifestyle people than in good-lifestyle ones. The changes in poor to good lifestyles through health education and learning were also shown to result in promotion of such health potentials.
\end{abstract}

Key words: lifestyle (ライフスタイル), health (健康), chromosome-DNA alterations（染色体遺伝子), natural-killer cell activity（NK細胞活性）, mental health（精神心理的健康度）

\section{序. ライフスタイル研究の今日的意義}

戦後におけるわが国の疾病死亡構造は, 結核等の 感染症から, がん, 脳血管障害, 心臟病, アレルギ 一，糖尿病などの慢性疾患へと急激に変化した。こ れらいわゆる生活習慣病の場合, 数十年にわたる日 常のライフスタイルが遺伝素因との複雑な交絡のも とに，その発症に大きな影響を及ぼしている1。つま

受付 1999年 8 月 18 日 受理 1999 年 8 月26日

Reprint requests to: Kanehisa MORIMOTO,

Department of Social and Environmental Medicine

Osaka University Graduate School of Medicine

2-2,Yamadaoka, Suita, Osaka, 565-0871, Japan

TEL: +81(6)6879-3920 FAX: +81(6)6879-3929

E-mail: morimoto@envi.med.osaka-u.ac.jp
り, 従来のような特定の病因により, 特定の疾病が 発症し, 死に至るという構図では, 現在の疾病, 健 康構造を説明することが不可能になっている。日常 の生活習慣にかかわる多様な要因と, 遺伝素因が複 雑に交絡して生ずる健康破綻を対象にした，新たな 医学医療体系が必要なゆえんである。

さらに，わが国のように平均寿命が伸び，経済的 にも，社会的にも，より豊かな生活を求めるように なってきた国々では, 健康を維持増進して疾病を予 防するとともに，日々の生活の充実感，生きがい感 を高めたいとの要求を, 多くの人が持つようになっ た。今や，人間一人一人が持つ人生の目標や，理想 的な生き方を支援するために，健康な時期に疾病を 予防する手たてを積極的かつ科学的に考え，同時に 生活の充実感（Quality of life, QOL）を高めていく方 
法を具体的に考究する医学の分野が必要とされている。 このような時代における新しい環境医学研究の課 題は, 個人あるいは集団レベルでのライフスタイル の醸成にかかわる多様な環境要因を総合的かつ科学 的に解析し, 将来における疾病発症 - 健康破綻の予 知予測と健康增進理論を確立し, 新たな医学医療の 実践体系を創設することにある。

\section{I．ライフスタイルと身体的健康度}

\section{1. ライフスタイル（健康習慣）の評価}

いま，ライフスタイルという用語は個々人の具体 的な日常生活習慣を表すとともに, より抽象化され た個人の生きざまや健康観, 人生観ともいうべき抽 象概念を表現する語として用いられている ${ }^{2)}$ このラ イフスタイルは, 一個の人間の誕生から現在に至る までの数十年間に社会や家庭で遭遇してきた，両親，
教師, 友人に代表される人間関係, あるいはテレビ や書物を通じての知識や思考方法を個人の内部で抽 象化しつつ蓄積し, 状況に応じて個性的に表現して いるものと規定できる。このような意味づけから， ライフスタイル環境とは, 個々人あるいはコミュニ ティー集団のもつ環境履歴の総体として把握すべき 質を持っている1-3)。

しかしここでは, ライフスタイルを日常生活習慣 としてモデル化し, 定量的に評価するために，8項 目（運動習慣，喫煙習慣，飲酒習慣，睡眠時間，栄 養バランス, 朝食摂取の有無, 労働時間, 自覚的ス トレス量）の健康習慣各項目について，森本の基準 に従って良い生活習慣（1）と悪い生活習慣（０） を設定し，二分法で 0 叉は 1 を得点として与え，そ の合計をHPI（健康習慣指数: Health Practice Index） 得点 ${ }^{4-6)}$ として各個人のライフスタイルを総合的に数 値化した（図 1)。

\section{該当 $7 \sim 8$ 個=良好 該当 $5 \sim 6$ 個=中屚 該当 $0 \sim 4$ 個=不良}

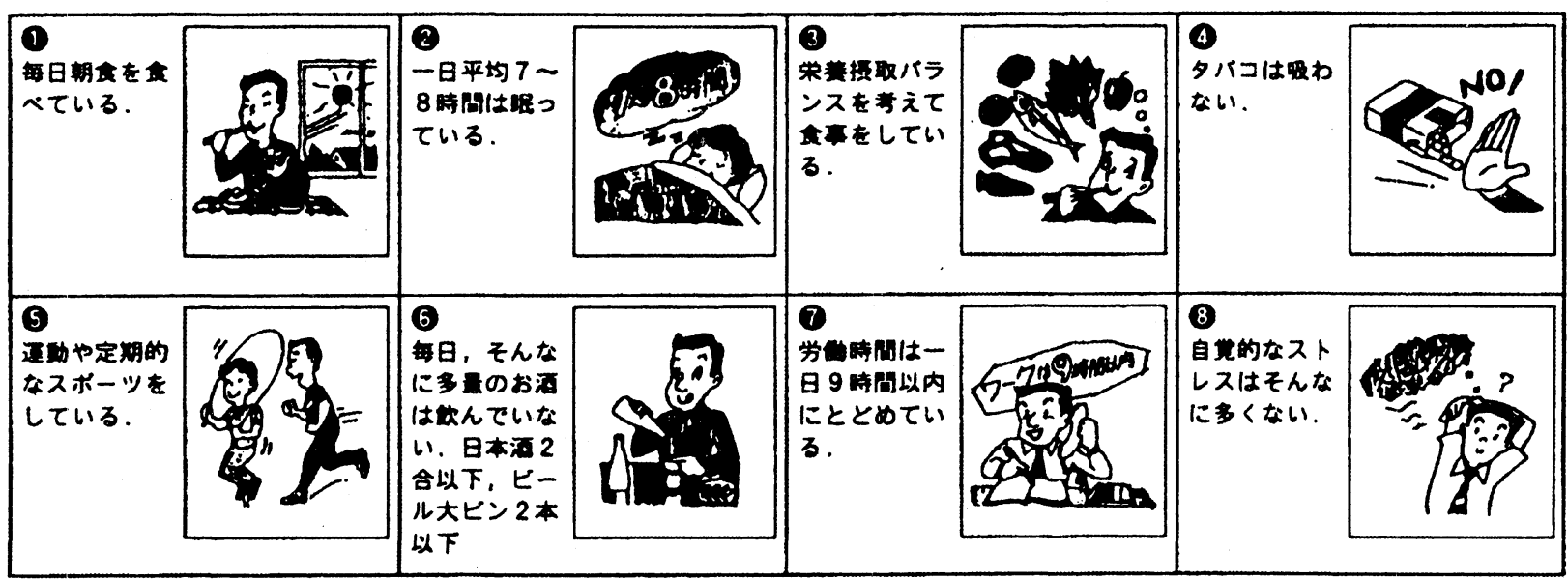

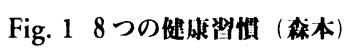

\section{2. ライフスタイル（生活習慣）特性の内的構造}

17項目の生活習慣における相互の関連について相 関係数を計算して検討すると（表 1 ), 男子では, 食 事の規則性が朝食の攝取と高い相関を有し，さらに 睡眠時間や生活の規則性とも相関が認められた。食 事内容に関して, 塩分摂取と栄養バランスが関連を 有している。

一方, 労働時間, ストレス, 多忙感などは相互に 弱い関連を有しており, 労働による精神的負荷の惹 起を示唆している。飲酒と喫煙は弱い相関があるが, 上記の項目との相関はみられず，喫煙から精神的な ストレスとの関連性についてはこの結果からは結論 が出せない。趣味の有無においても同様である。

女性においても基本的に同じ関係が成り立ってい るが, 間食と労働時間について男子でみられた関連 が認められない。
17項目の生活習慣の分布（表 2 ）をみると男女と もに，食事に関する項目で悪い習慣の頻度が高く, 特に，栄養バランスを考えない，塩分制限をしてい ない，間食を毎日するという項目が多い。男性では， 労働に関するもので, 長時間労働時間, 多忙感, 過 度のストレスの自覚, 及び睡眠時間の不足が見られ る。女性では, 多忙感やストレスの自覚, 睡眠の不 足は男性と同じ程度に見られるが, 労働時間の超過 は見られない。

趣味の活用，運動習慣は男女で同じように低いの に対し，飲酒，喫煙習慣は，男性が非常に高い。喫 煙に関しては, 日本男性の平均喫煙率（55\%）と等 しい結果であった。

このような違いがあるにもかかわらず，男女での 生活の規則性, 食事の規則性, 及び生活渵足度がほ ぼ同じ水準であることは興味深い。 
日衛誌（Jpn. J. Hyg.）第54巻 第 4 号 2000年 1 月

Table 1 生活習悍相互の関进性（Pearson's Correlation Coefficiency) (在上段：男性, 左下段：女性)

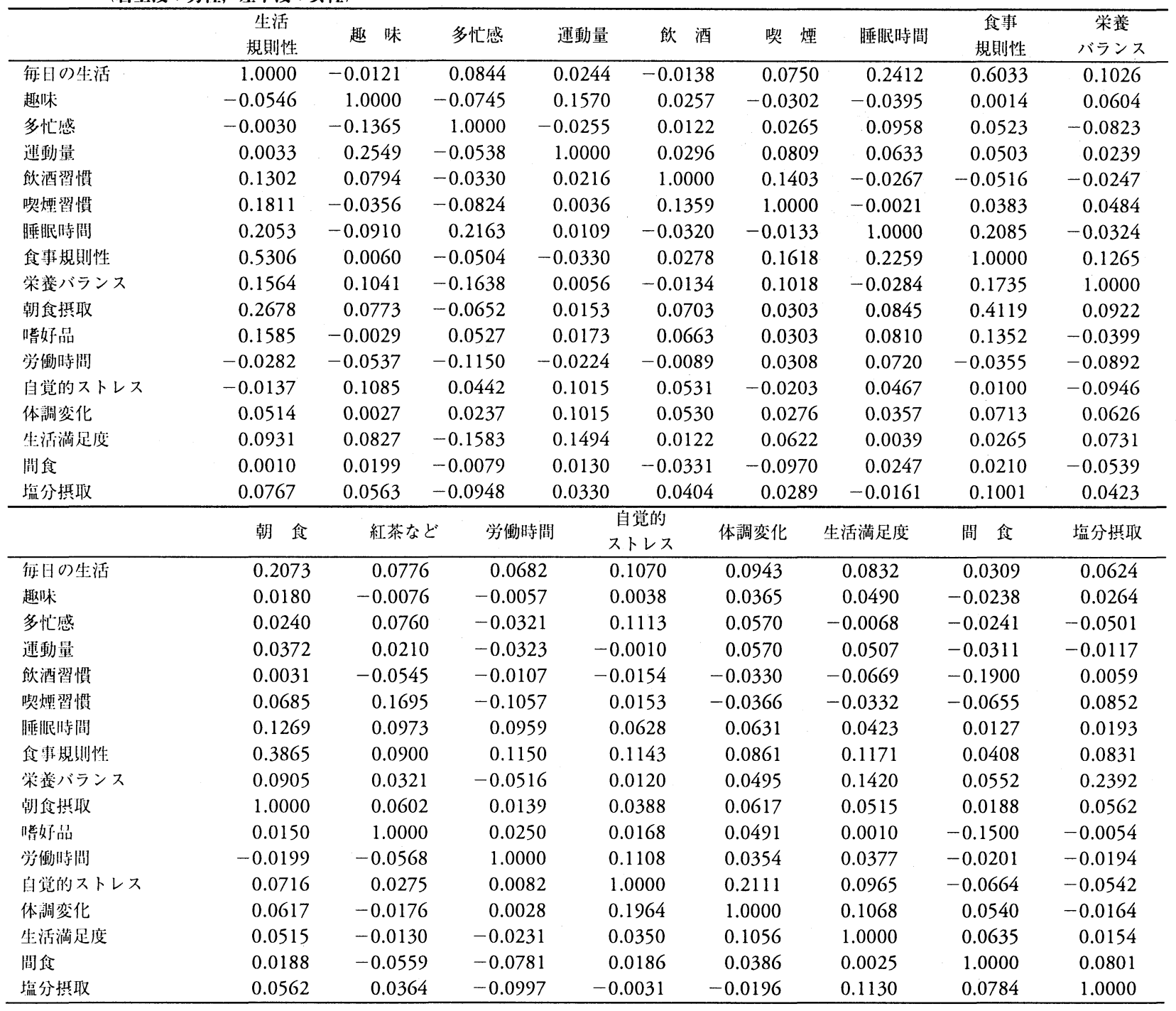

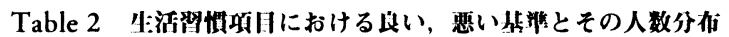

\begin{tabular}{|c|c|c|c|c|c|c|}
\hline & \multicolumn{3}{|c|}{ 悪い } & \multicolumn{3}{|c|}{ 良い } \\
\hline & \multirow{2}{*}{ 基 準 } & \multicolumn{2}{|c|}{ 人 数 } & \multirow{2}{*}{ 基 準 } & \multicolumn{2}{|c|}{ 人 数 } \\
\hline & & 男 性 & 女 性 & & 男 性 & 女 性 \\
\hline 伍日0生活规則性: & 不規则 & 328 & 113 & 規則的 & 1,292 & 414 \\
\hline 趣味 & ない & 93 & 104 & ある & 1,527 & 423 \\
\hline 多忙感 & いつも忙しい & 675 & 213 & あまり忙しくない & 945 & 314 \\
\hline 速動 & 月 1 回以下 & 937 & 409 & 週 1 回以上 & 683 & 118 \\
\hline 领渔 & 每日 & 649 & 27 & 時々飲む/飲まない & 971 & 500 \\
\hline 喫煙 & 吸っている & 882 & 59 & やめた吸わない & 737 & 468 \\
\hline 睡眠時間 & 6 時間以下/9 時間以上 & 577 & 251 & $7 \sim 8$ 時間 & 1,043 & 276 \\
\hline 食事規則性 & 不規則 & 414 & 129 & 規則性 & 1,206 & 398 \\
\hline 栄䓯バランス & 考えていない & 1,373 & 422 & 考えている & 247 & 105 \\
\hline 胡食 & 件日とらない & 337 & 127 & 短日とる & 1,283 & 400 \\
\hline 㖺好品 & 1 日 5 杯以上 & 154 & 26 & 1 日 4 杯以下 & 1,466 & 501 \\
\hline 学働時間 & 10時間以上: & 959 & 90 & 9 時間以下 & 661 & 437 \\
\hline 自営的ストレス量 & 多い & 632 & 212 & 少ない/中程度 & 988 & 315 \\
\hline 体洞変化 & 覀くなった & 230 & 75 & 同じ/良くなった & 1,390 & 452 \\
\hline 生活嗬起度 & 少ない/ない & 1,218 & 398 & かなり/大いに & 402 & 129 \\
\hline 開食 & ほとんど毎日 & 879 & 438 & あまりしないしない & 741 & 89 \\
\hline 塩分掑取 & 控えない & 1,346 & 411 & 控えている & 274 & 116 \\
\hline
\end{tabular}




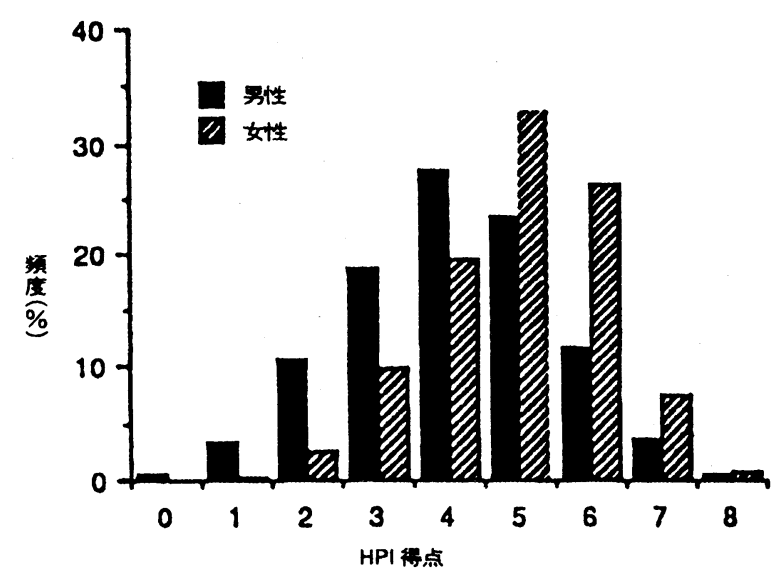

Fig. 2 罗女别HPI埱占の分布

HPI得点の分布を図 2 に示した。男子はカイ自乗検 定で正規分布していることが確認できるが，女性は 高い得点側にピークがシフトしている。男性の平均 HPI得点は $4.07 \pm 1.44$, 女性の平均HPI得点は $4.96 \pm$ 1.23で女性が約 1 点, 有意に高かった。また, 年齢の 増加と共にHPI得点が増加する傾向がみられた。

\section{3. 発症リスクファクタによる身体的健康度評価}

全対象者（男女 2,148 名）を男女別10歳ごとの年齢 階級に分割し, 検査項目は臟器及び機能別に分け, （1）肝機能 (GOT, GPT, ALP, HBs, ZTT)，（2）貧 血 (赤血球数, $\mathrm{Hb}, \mathrm{Ht}$ ), (3) 炎症反応（白血球数,
CRP)，（4）尿検查（糖，蛋白， ウロビリ，潜血）, （5）血糖值，（6）総コレステロール (TCh)，（7）尿 酸，（8）血圧の 8 つとした。各検査值に一つでも異 常值があれば異常 (1), 正常值のみであれば（0) を与え，合計得点をINDEXとした。

ここで正常值とは, 本検査を担当した京都医学研 究所に打ける 7 年間の約 20,000 名の基礎データから平 均值 $\pm 2 \mathrm{SD}$ 以内の值を設定した。また, 血圧はWHO の基準に従った。

このINDEXの得点に基づく度数を性別・年齢別に 求め, RIDIT值を算出した。平均RIDIT值は50であり, 増加と共に異常值が増加, 寸なわち健康度が悪化す ることを意味する》。

検査值の異常頻度から作成した 8 つ健康度群分 布から外的基準（INDEX）を計算した。この分布を 基に各INDEXに属する者のRIDIT值を計算した》。つ いで年齢別に各HPIごとに平均RIDIT值を計算すると， HPIの上昇と共に平均RIDIT值の減少が見られた。 HPIをその分布に従って $0 \sim 4$ 点, $5 \sim 6$ 点, $7 \sim 8$ 点 の 3 つに層別化し（図 1)，これらの関係を検討した。

その結果， 6 年間すべての年代を通じて年齢を固 定した場合，HPIが高いほどRIDIT值は低く，HPIを 固定した場合，年齢が増すにつれてRIDITが上昇し， 健康度が低下する。年齢を固定した場合のHPIによる RIDIT值への影響は，年齢が高いほど大きい，つまり， ライフスタイルの影響による検査異常值の出現は, 30 40歳代では最も大きく寄与するが, 加療を要す るほどには健康度は低下しない。一方，50歳以上で

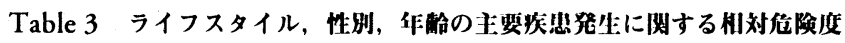

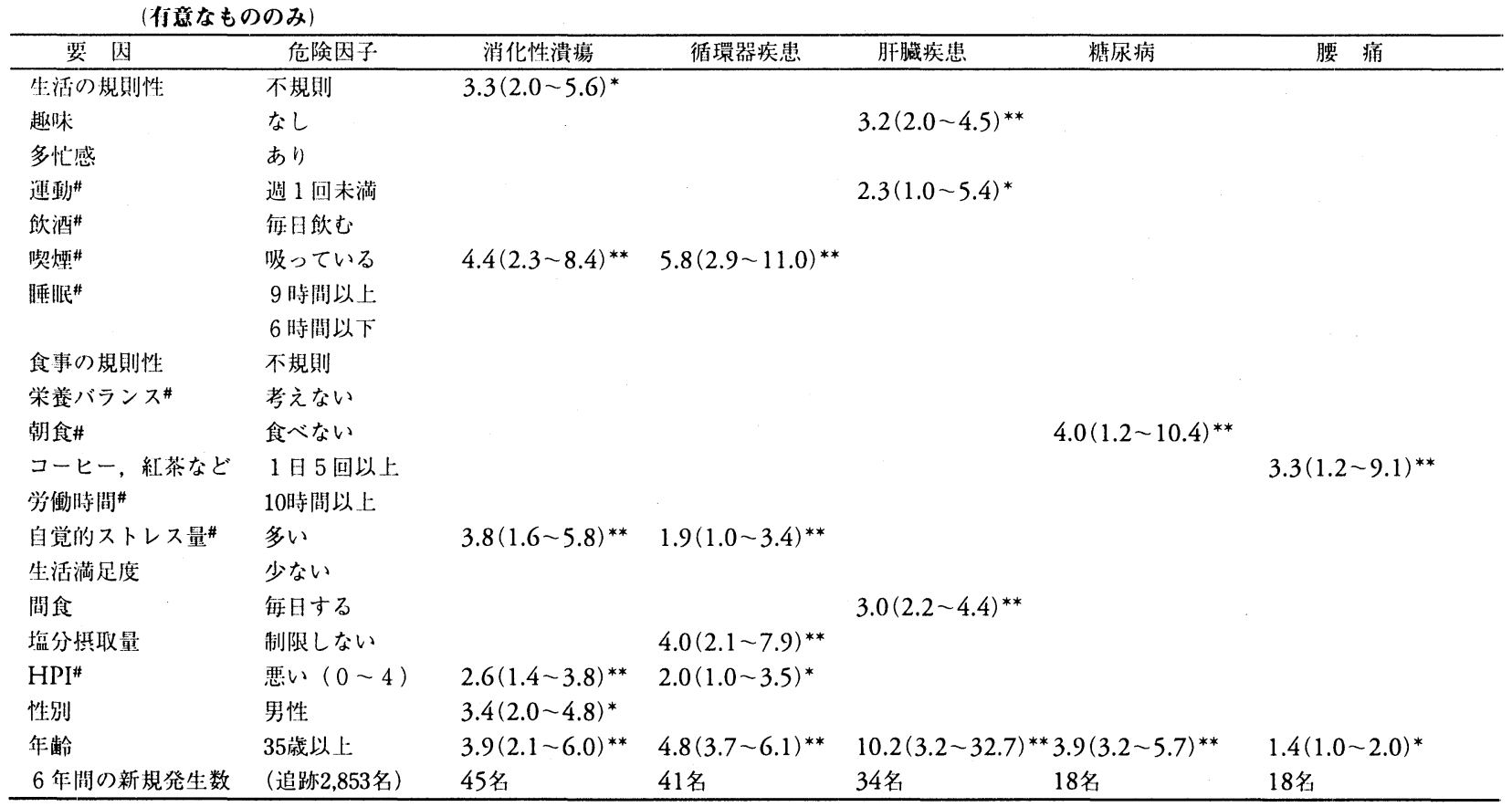

\#: HPI関連項目.

${ }^{*}: \mathrm{P}<0.05,{ }^{* *}: \mathrm{P}<0.01$. 


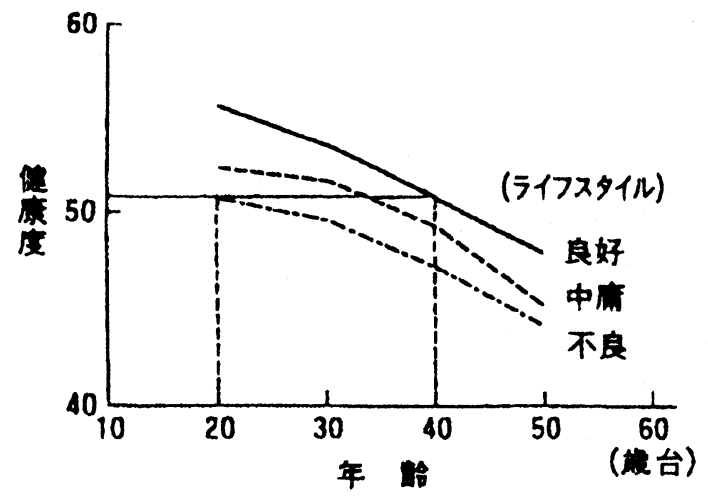

Fig. 3 ライフスタイルと加畧による健康度低下

は異常値を有する者の多くは加療が必要となり，健 康度が著しく下がることになると結論される（図 3 )。

\section{4. ライフスタイルによる将来の健康破綻予知}

ライフスタイル環境要因が検査値の異常の出現に 寄与し，その結果，様々な疾病が発症するならば, 各個人のライフスタイル要因を検討することによっ て，将来の疾病の発生を予測することが可能となる。
そこで，昭和59年から平成元年まで（1984-89）の 6 年間に新たに発生した疾患について，ライフスタイ ル要因とHPIの疾患発生への寄与度を, 多重ロジステ イックモデルにより評価した。

まず，この 6 年間に新たに発生した疾患の頻度を 求めた。これらの疾患のうち特に多い 9 の疾患（高 血圧, 糖尿病, 心臓病, 腰痛, 鼻疾患, 潰瘍, 肝臓 病，痛風，外傷）について，多重ロジスティックモ デルを用いて各疾病発生に対するライフスタイル要 因の寄与度を算出した（表 3 ）。

\section{II. ライフスタイルと免疫・アレルギー反応}

\section{1.ライフスタイルとNK細胞活性（がん免疫力）}

8 つの健康習慣（図 1) の各項目ごとにNK活性を 評価した。飲酒習慣を除く 7 項目について，健康習 慣を守っている者の方が高いNK活性を示した8.9)（図 4 )。特にLU (Lytic Unit) 值から相対的なNK活性の 影響力を評価すると，最も大きな影響を及ぼすのは 運動習慣（107細胞当たりのLU1.47），自覚的ストレ 又量 (1.45)，睡眠時間 (1.44)，喫煙 (1.27)，栄養バ ランス（1.37）であった。この調査では, 飲酒の有無
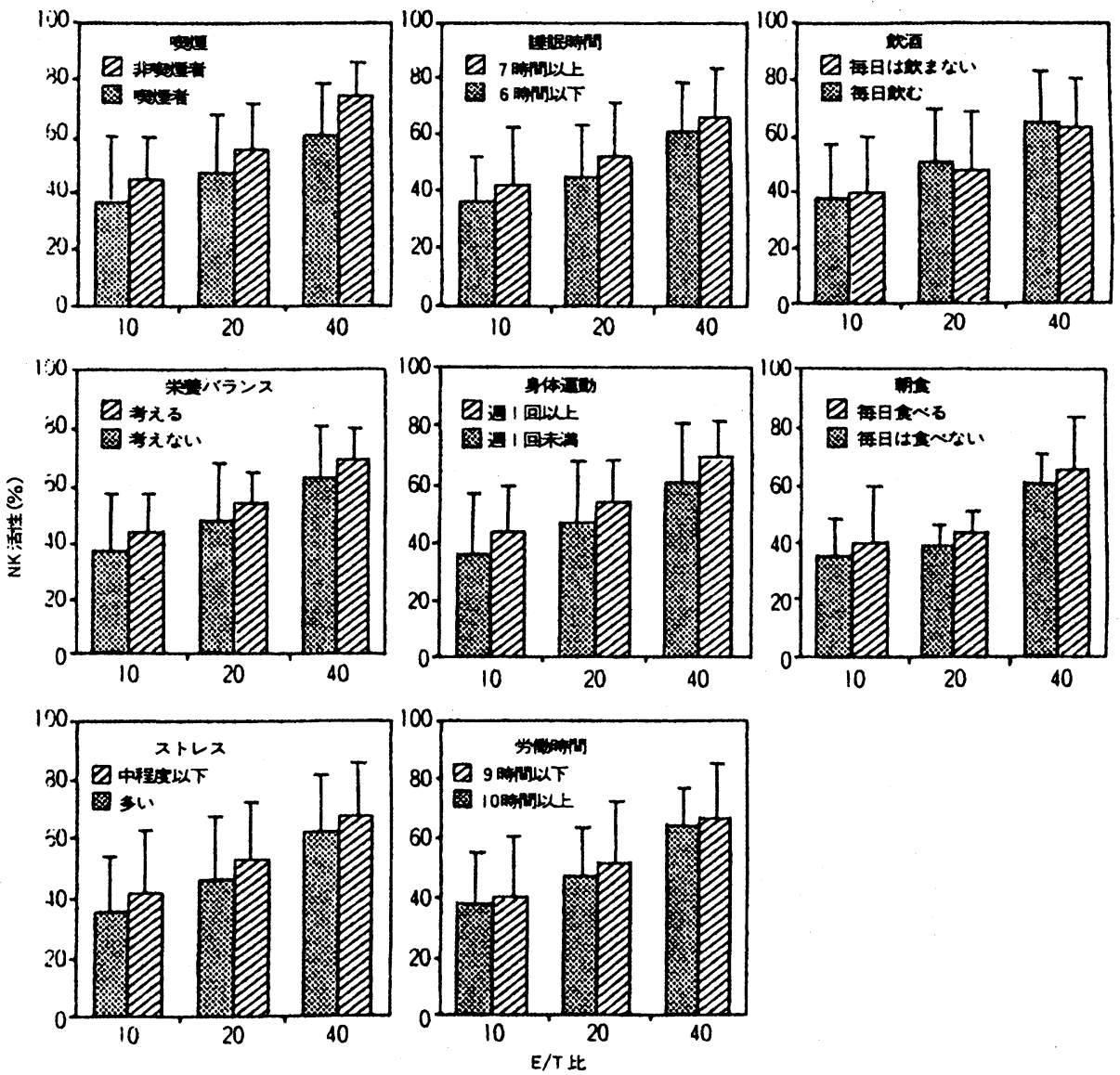

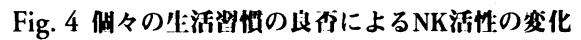


E/T 40

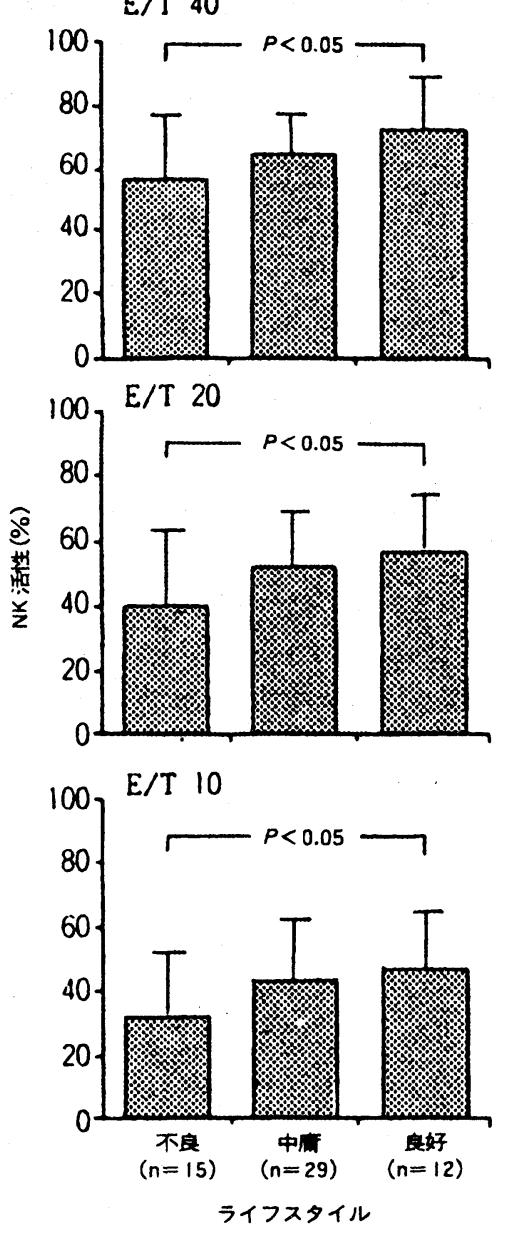

Fig. 5 ライフスタイルとNK活性

Table $4 \mathrm{CD}^{2} 6^{+}, \mathrm{CD} 57$-細胞 1 倜あたりのNK活性:

\begin{tabular}{|c|c|c|c|}
\hline \multirow{2}{*}{ ライフスタイル } & \multicolumn{3}{|c|}{ NK活性 } \\
\hline & $10: 1$ & $20: 1$ & $40: 1$ \\
\hline 良好 $(n=13)$ & $12 \pm 2$ & $16 \pm 7 *$ & $21 \pm 9$ \\
\hline 中庯（ $n=32 ）$ & $10 \pm 5$ & $14 \pm 7$ & $17 \pm 7$ \\
\hline 不良 $(n=17)$ & $8 \pm 3$ & $11 \pm 5$ & $17 \pm 7$ \\
\hline
\end{tabular}

によるNK活性への影響は全く見られなかった（LU比 は1.00)。

ライフスタイル群ごとにNK活性を評価した結果, 3つのE/T比（Effector to Target Cell Ratio）の何れに ついてもライフスタイル良好群のNK活性はライフス タイル不良群のそれよりも有意に上昇していた（図 5 )。

さらにフフローサイトメトリ（FACS）法により $\mathrm{CD} 16+, \mathrm{CD} 57$-の表現型を示すNK細胞 1 個あたりの NK活性を測定したところ，ライフスタイル良好群ほ ど有意に上昇していた（表 4)。従って，このNK活性 の上昇は，NK担当細胞数の増加によるというより， NK担当細胞 1 個 1 個のNK活性の上昇によることが示 唆された。
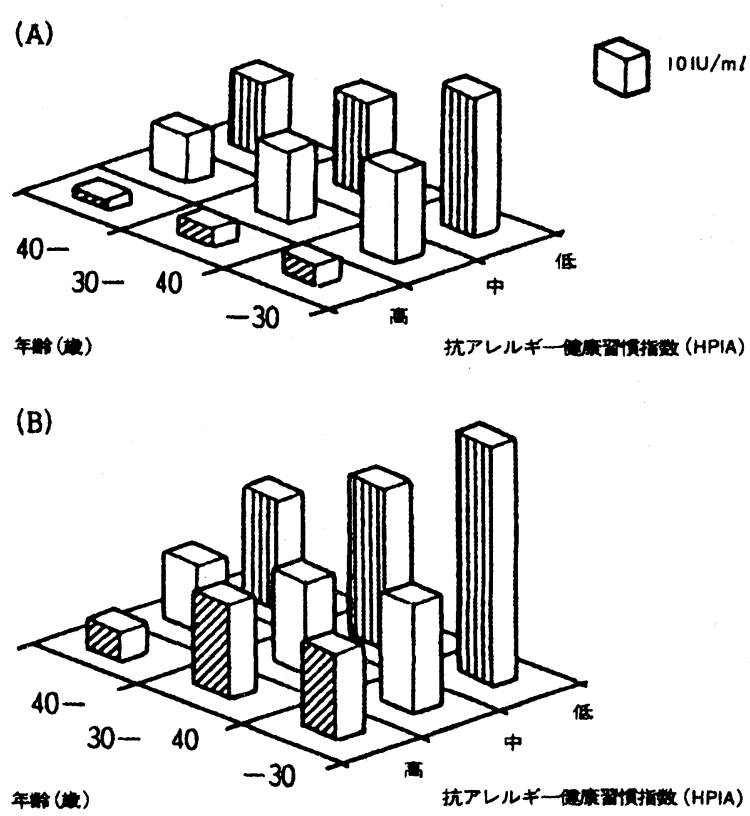

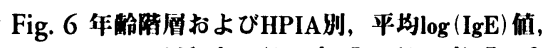
HPIAは低 $(0 ４)$ ，中 $(5 － 6)$ ，高 $(7 － 8)$ に分けられる

\section{2. ライフスタイルと血清 $\lg E$ 值 ${ }^{10-19)}$}

日常生活習慣について良い習慣群と悪い習慣群の $\mathrm{IgE}$ 值の差が 3 つに分かれることが判明した。すなわ ち，良い習慣群の方が悪い習慣群に比べて IgE值が高 い項目，低い項目，ほとんど等しい項目の3つであ る。そこで多元分散分析（MANOVA）を用いて， $\mathrm{IgE}$ 值を上げる項目と下げる項目を選択した。その結 果，良い習慣を持つ場合にIgE值を上昇させる因子IFs (Increasing Factors) として5つ（自覚的ストレス 量, 運動量, 睡眠時間, 労働時間, 趣味の有無) が 抽出され，一方， I g E 值を下げる因子 D F s (Decreasing Factors) として3つ（飲酒，喫煙，多忙 感）が抽出された。これらの項目について，良い習 慣を1点, 悪い習慣を 0 点として, 各個人についてIFs, DFsについて合計得点を計算すると, IFsは0-5点, DFsは0-3 点の分布となる。

そこでライフスタイル環境の指標として, 抗アレ ルギー健康習慣指数 (Health Practice Index in Allergic Reaction: HPIA）を以下の式により計算した。 HPIA $=$ DFs $+(5$-IFs $)$

この式からHPIA得点は $0-8$ 点に分布し, HPIAが高 いほどIgE值が低くなる。 $\log (\mathrm{IgE}$ ) 值を, HPIAの 3 群 (0-4,5-6,7-8) と年齢層で分けた結果を図 5 に示す。年齿層ごとにみると, HPIAが大きくなるに 伴って IgEも有意に減少し, HPIA群ごとにみると, 年 齢の増加に伴って $\operatorname{IgE} の$ 有意な減少が見られる ${ }^{15-19)}$ (図 6 )。

$\mathrm{IgE}$ 值が平均+2SDに相当する $400 \mathrm{IU} / \mathrm{ml}$ 越えると, アレルギー発症の頻度や皮膚テスト陽性率, 好酸球 の上昇等が増加すると報告されており ${ }^{1-8.10)}$ ，この值 


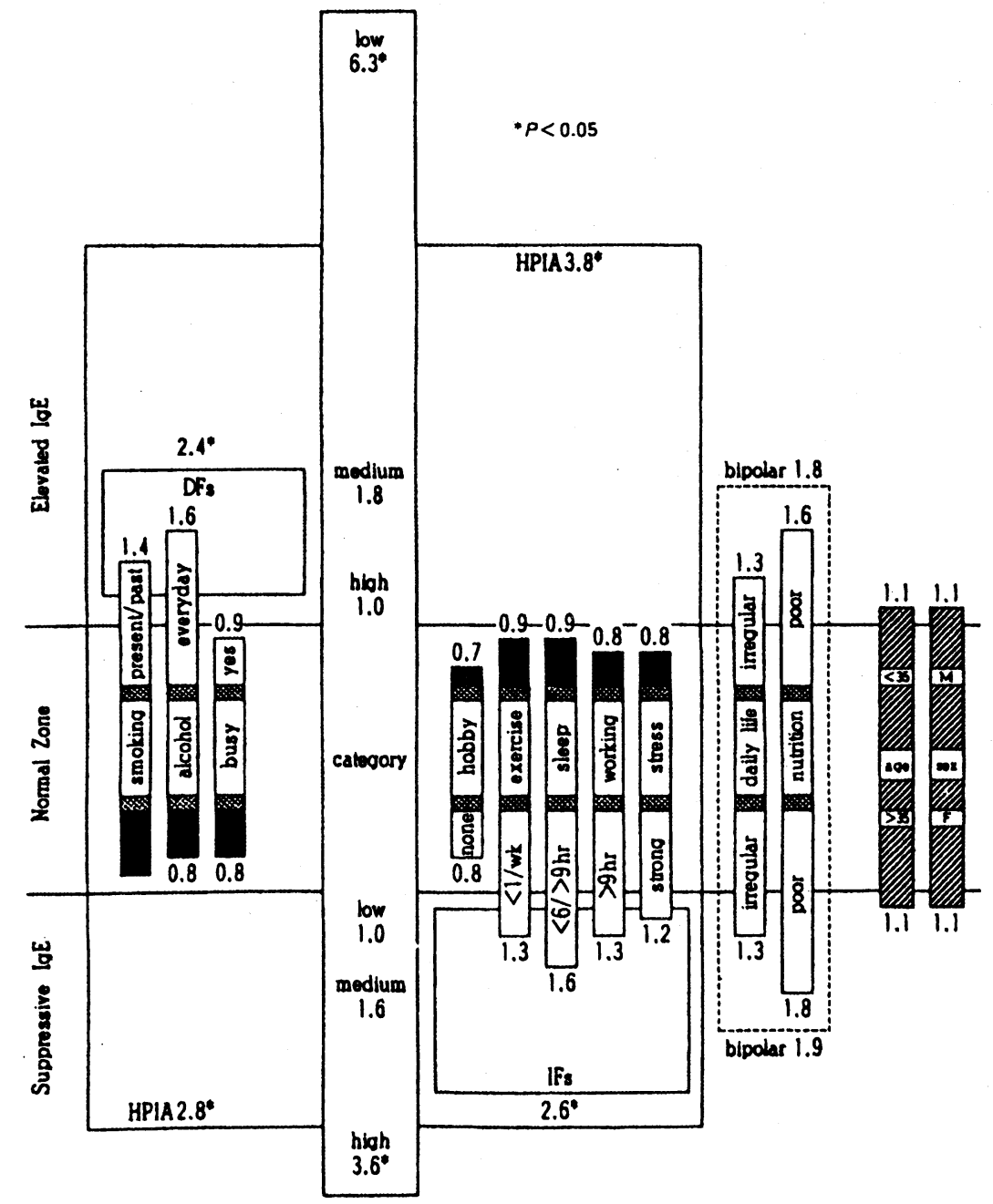

Fig. 7 ライフスタイル要团によるHPIAのリスク䐂侕

をカットオフ值とした。これに対して IgEが平均-2SD よりも低い值 $5 \mathrm{IU} / \mathrm{ml}$ での意味づけは現在のところ不 明である。しかし， IgE值が高い集団ではがんの発生 率が低いこと, 低IgE值群では気道の感染を繰り返し 易いこと, IgA低值では $\operatorname{IgE}$ 值が増加して感染防御に 働くことなどから, IgE低值では何らかの免疫防御機 構の破綻が考えられる。最近になってSaxonらのグル ープは, NK（Natural Killer）細胞がIgE值をコントロ ールしているとの報告を出しているが, NK細胞活性 が低下する。NK細胞は, 喫煙, 飲酒, ストレス等の ライフスタイル要因によって影響を受けることが知 られておりこうした因子によってNK細胞活性が低 下したとすれば, IgE低值はNK細胞活性等の免疫活 性が抑制された状態と考えられる。そこで $5 \mathrm{IU} / \mathrm{ml}$ 免疫抑制状態と定義し,アレルギー反応感受性リス クのカットオフ值とした。

その結果を図 7 に示す。IFsを構成する 5 つの因子 のうち単独で有意なリスクをもつ因子はない。しか し，これらの 5 つの因子から構成されるIFsは総体と
して, IgEを $5 \mathrm{IU} / \mathrm{ml}$ 以下に下げる有意なリスクをも つ。一方，DFsを構成する 3 つの因子のうちで，多忙 感を除く 2 つはある程度のリスクは有するもののや はり単独で有意なものはない。ところが，IFsと同じ くDFsも大きなリスクをもっており，これらを総合し たHPIAはIgE上昇にも減少にも大きなリスク因子とな りうる(図 7 )。

栄養バランスが不規則である場合は，IgEを上昇さ せる方にも, 減少させる方にも, ある程度のリスク を有している。これをさらに細かく検討するために， $\mathrm{IgE}>400 \mathrm{IU} / \mathrm{ml}$ と $\mathrm{IgE}<5 \mathrm{IU} / \mathrm{ml}$ での肥満係数BMI (Body Mass Index) を検討すると，IgE高值群では BMIが正常值群に対して高い傾向にあり, 一方, IgE が低值では有意に瘦せた者が多いことが判明し，こ れまでの報告と一致する。

これらの結果から, HPIAを構成する1つ1つの生 活習慣を単独で, IgEをアレルギーの発症するレベル $(>400 \mathrm{IU} / \mathrm{ml})$ や免疫抑制を起こしていると考えられ るレベル $(<5 \mathrm{IU} / \mathrm{ml})$ まで有意に下げるリスクとは 


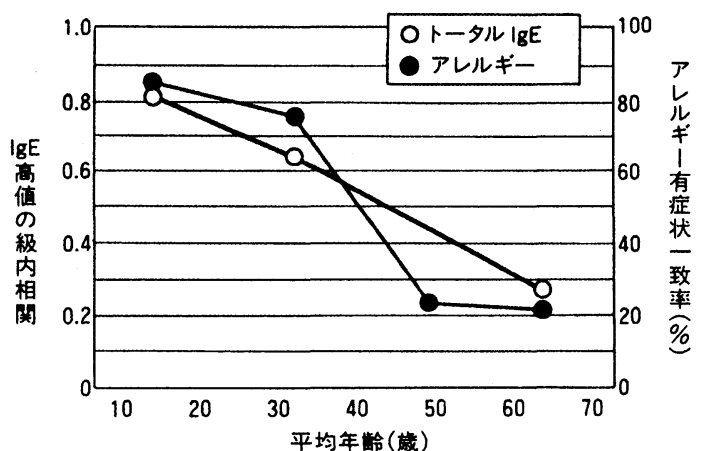

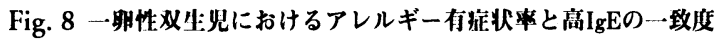

なりえない。一方，IgE值を上昇させたり減少させた りする因子を統合したIFs，DFs，そしてこれらをあ わせた因子としてHPIAを導入することで初めて有意 なリスクが形成される。

$1 つ 1 つ の$ 生活習慣によるIgE值の変動は小さい が，それらをまとめた包括的なライフスタイルとい う概念（この場合はHPIA）を導入することによって， 初めてライフスタイル環境がIgE值に有意な影響を与 えて事実が示される。

これらの結果は各個人のIgE值をモニターすること で, 生体中のさまざまな免疫反応に及ぼすライフス タイル要因をモニターする貴重な方法を手に入れた ことを示唆するかもしれない。

\begin{tabular}{|c|c|c|c|c|}
\hline 染色体番号 & アトピー & 喘息 & 湿捡 & 鼾カタル \\
\hline 1 & CD1, IL10, STAT & HMT & & \\
\hline 2 & & IL1cluster, IL8R & & \\
\hline 3 & & & & \\
\hline 4 & IL2 & $\alpha_{2} \mathrm{ADR}, \mathrm{ET} 1$ & & \\
\hline & & ETRA & & \\
\hline 5 & $\begin{array}{l}\text { IL4, IL5, IRFI } \\
\text { IL } 13, \text { IL9, IL12 } \beta\end{array}$ & PDGFR $\beta, \beta_{2} \mathrm{ADR}$ & & \\
\hline 6 & HLA & $\mathrm{TNF} \alpha, \mathrm{LT}$ & TAP & $\begin{array}{l}\text { HLA-DP, } \\
\text { DQ, DR }\end{array}$ \\
\hline 7 & $\mathrm{TCR} \gamma, \mathrm{TCR} \beta$ & IL6 & & \\
\hline 8 & & & & \\
\hline 9 & & & & \\
\hline 10 & & & & \\
\hline 11 & Fce RI $\beta, H T m 4$ & $\mathrm{CC} 10$ & & \\
\hline 12 & IFN- $\gamma$ & & & \\
\hline 13 & ESD & HTR2, ETRB & & \\
\hline 14 & $\mathrm{TCR} \alpha / \delta, \operatorname{IgH} \varepsilon$ & & $\mathrm{MCC}$ & \\
\hline 15 & & & & \\
\hline 16 & & & & \\
\hline 17 & IL4R & & & \\
\hline 18 & & & & \\
\hline 19 & & & & \\
\hline 20 & CD23 & & & \\
\hline 21 & & & & \\
\hline 22 & & & & \\
\hline $\mathrm{X}$ & IL2R $\beta$, IL 3R $\beta$ & & & \\
\hline $\mathrm{Y}$ & CD4OL & & & \\
\hline
\end{tabular}

\section{III. アトピー遺伝子}

\section{1.アトピー遺伝子と環境}

筆者らは，一卵性双生児の同胞におけるア レルギー疾患保有の一致率, ならびに血清中 $\mathrm{IgE}$ 高值の一致率を指標とし，その年令依存性 について興味ある結果を得た（図 8)。

言うまでもなく, 一卵性双生児の同胞間で は，事実上，その遺伝子構成は全く同一であ り，いわば，コピー人間そのものと言って良 い。もちろん，それは遺伝子(ゲノム)につ いてのみであり，人間としての人格は全く別 人であることは言うまでもない。この図 1 に みるごとく小児科領域ではこれらアレルギー 疾患の保有と $\mathrm{IgE}$ 高值の一致率は共に $80 \%$ 以上 であるが，高齢者（老人科領域）では，この 遺伝と環境との寄与割合が逆転し，わずか $20 \%$ 一致をみるのみである。医学医療の中 でも，小児科領域について，アトピー遺伝子 が最も重要な関心事である科学的根拠がこの 図にあるともいえる。

本稿では，これらアトピー候補遺伝子（表 5 ）について, 最近の知見を我々の研究成果 を中心に紹介し，筆者のアレルギー発症にか かわる意見も述べてみたい。

\section{2. $\lg E$ 受容体（Fc $\varepsilon \mathrm{RI} ）$ と遺伝的インプリン ティング}

$\mathrm{Fc} \varepsilon \mathrm{RI}$ は，マス卜細胞，好塩基球，ランゲ

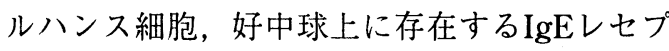
ターでアレルギー反応のかなめとなる重要な 分子である。その詳細については，本特集の 他稿を参照されたい。この分子は $\alpha \beta \gamma_{2}$ の四 量体を形成しており， $\alpha$ 鎖に結合したIgE抗体 からのシグナルは, シグナル伝達の共通のモ チーフをもつ $\gamma$ 鎖と $\beta$ 鎖を経由して細胞内に 伝達され, 脱顆粒現象が起こる。従って,こ れらの分子に異常が生じるとシグナル伝達に 変化が生じる可能性があり, 候補遺伝子とし て重要である。

約10年前から, 逆行性遺伝学の手法が使用 されるようになり，2人の英国人，Hopkin， Cooksonはこの手法を用いて, アトピーの遺伝 子を同定しょうと考えた。彼らは，7年にわ たり，ひたすら 300 家系のサンプルを集め， VNTRマーカーを用いて連鎖解析を行い，第11 染色体長腕マーカーD11S97に, “偶然”にも強 い連鎖を見出した。そこで，いくつかの家系 を用いて連鎖解析を行うと, 高いロッド得点 （5.8）を得た。さらに別の64核家系を調查して これを確認した。その後, この染色体上を中 

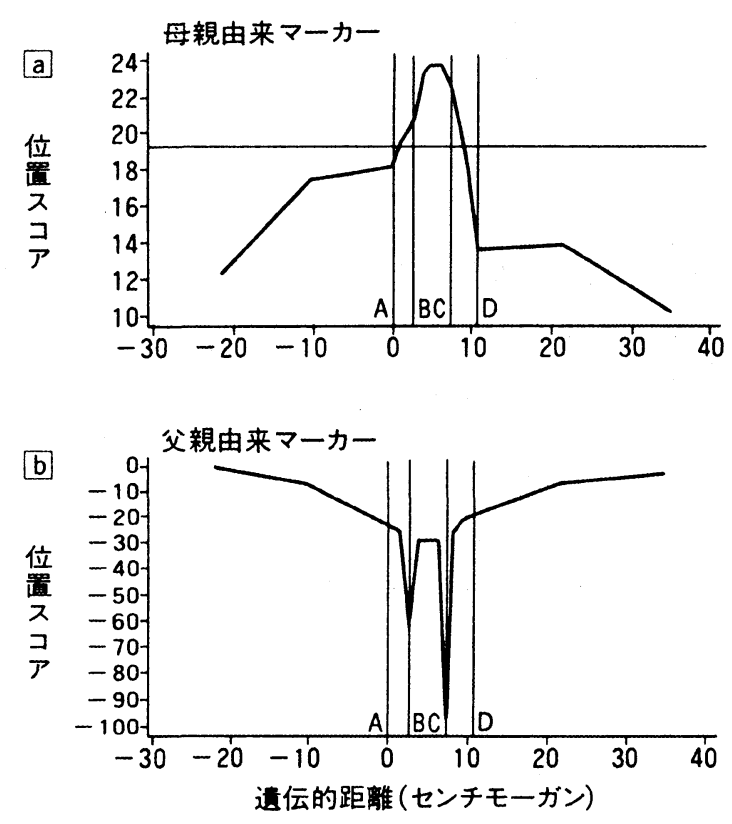

回は母親からのマーカー，回は父親からのマーカーを示す。母 親からのマーカーによる位置スコアはC マーカー $(\mathrm{F} c \varepsilon \mathrm{RI} \beta)$ の近 傍でピークに達しており，一方，父親のマーカーでは谷底を示す。 このことは、マーカーCの近傍にアトピー遺伝子座の存在するこ とを示している。位㯰スコアは10以上で有意と考えられる

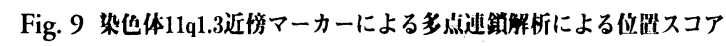
(Shirakawa et al.)
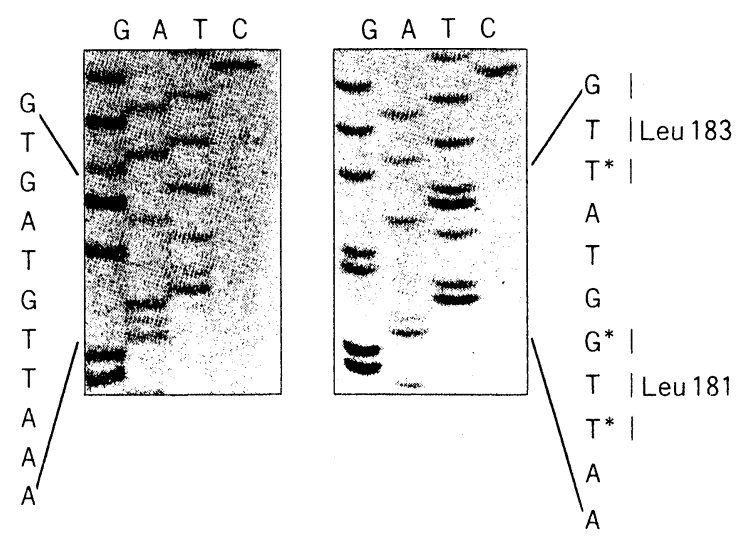

Fig. 10 第6エクソンにおけるLeu 181, 183 (TTG) 買変のシークエンス (Shirakawa et al.)

心部に向かって多点連鎖解析を行うと, マーカー319 とCD20の間でロッド得点が最高になることを確認し た。この間の遺伝学的距離は $4 \%$ （約 $4 \mathrm{M} \mathrm{b}$ ) 程度 であった。

マウスとラットのcDNAの配列をもとに，プライマ 一を設計し, PCR (polymerase chain reaction；ポリ メラーゼ連鎖反応）を行ってヒト $\beta$ 鎖のシークエン スを決定した。その結果, 第 5 イントロン内に非常 に多型性の高いCAリピートが発見され，これを用い てこの近傍のCAリピートとの多点連鎖解析を行った が, 母親由来のマーカーについてのみ, 組換え率が 上昇し，有意なピークが得られた（図 9 )。この現象
は, 父性インプリンティングあるいは授乳などによ る母性の存在を暗示している。

従来われわれの 2 本の相同染色体には父親と母親 の双方の同一遺伝子が存在し, 両方とも同等に発現 される (co-dominant) と考えられており, 免疫グロ ブリンのように片親の遺伝子のみが使用されるのは 例外と考えられてきた。ところが，現在，マウスで は 5 つの遺伝子が両親のいずれか片方の遺伝子のみ 使用していることが報告され，この現象がかなり広 く行われていることが示唆されている。 $\beta$ 鎖が存在 する第11染色体長腕13領域と相同のマウス領域では, $5 \mathrm{H}$ 遺伝子がありインプリンティングされると考え られており，ヒト $\beta$ 鎖もインプリンティングされて いる可能性もある。また, インプリンティングが起 こり，母親からの遺伝子のみが発現されるとすれば, 正常な祖父母から正常な父母を経由して第 3 世代に アトピーが発現する形式をうまく説明できることに なる。

ついでFc $\varepsilon$ RI $\beta$ 遺伝子がアトピー遺伝子であるか を検討するため, 正常児 6 名とアトピー児 6 名を対 象として, 全 7 エクソンのシークエンスを比較した。 その結果，図10に示すように，第6エクソンにアミ ノ酸変異を伴う变化を認めた。これらの変異は 1 個 体について1変異であるので，アトピーを規定する 变異と考えられた。

これらの変異率を求めるために，P C R を利用し たテストを行った。変異の上流に 5 ’プライマーを設 計し, 変異域に野生型拉よび変異型のプライマーを 設計して, PCRを行い, 変異型を決定した。第 6 エク ソンでの, 第181アミノ酸のイソロイシンからロイシ ンへの変異 (Leu181) と, 第183アミノ酸のバリンか らロイシンへの変異 (Leu183) は最初, 第11染色体 との連鎖を強く認めた大家系にみられたため, まず これらの変異について調査した。

英国中部のオックスフォード州内での一般外来患 者の集団では，約 $10 \%$ にeu181変異を認め，この変 異を有する $\beta$ 遺伝子頻度は $5 \%$ と推定された。一方, Leu183変異は全く認められなかった。この変異 Leu181陽性者の半数はアトピーはなく，インプリン ティングを支持する結果であった。また，この変異は 総 IgE值, およびいくつかの植物抗原 $\operatorname{IgE}$ と関連がある が, ダニ抗原 IgEとは関連がないことが判明した。し かし, 特異 IgE抗体との関連の機序は明確ではない。

次に，母親系列の遺伝样式を明らかにするため, 核家族100家系でのARMSテストを行った。その結果, 10 家系にこの変異を認め（図11），母親10名全員が変 異陽性であり，父親は全員陰性であった。また，ア トピー患児12名のうち，10名はこの変異が陽性であ り, 残り 2 名は父親から別の遺伝子を受け継いだと 考えられた。

以上の結果から，英国人ではアトピー患者の約 

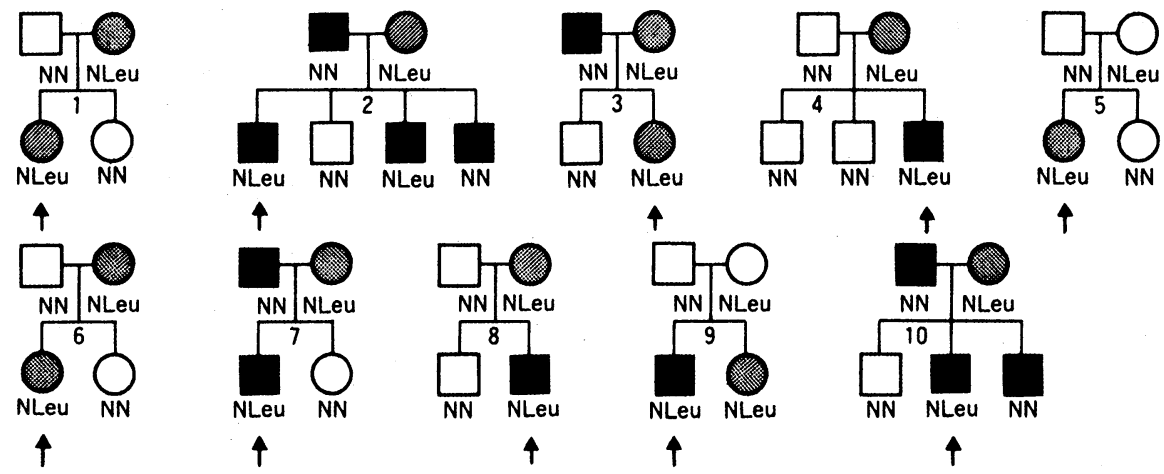

10家系のすべての母親は Leu 181陽性である。一方，父親はすべて陰性である。アトビー児14名 中12名は Leu 181 陽性で, 残りの 2 名の父親 $(2,10)$ はアトピーであり, この 2 児は父親からのほ かの遺伝子の遺伝と考えられる

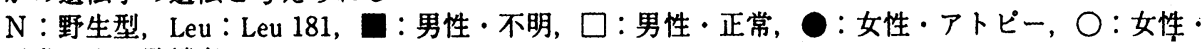
正常, $\uparrow:$ 発端者

Fig. 11 Leu 181を認めた10家系における，この変恭の䢐伝子形式（Shirakawa et al.）

15\%がこのLeu181変異と関連していると考えられる。 連鎖解析の結果から，アトピーの約 $60 \%$ は第 11 染色 体に連鎖していると考えられることから, Leu181変 異は $\beta$ 遺伝子内での主要な変異と考えられない。従 って，この $\beta$ 遺伝子のLeu181変異はアトピーを規定 する変化ではなく，このすぐ近傍にある遺伝子がそ の本体という考え方も成立する。筆者らは日本人を 対象に100家系でこのLeu181の変異の有無を検討した が, 残念ながら 1 名もこの変異を持っていなかった。

\section{3. 第 5 染色体・第12染色体上のアトピー候補遗伝子}

アトピー遺伝子がIgE抗体の制御遺伝子であるとす れば，IgE産生を制御するサイトカインは，その最も 良い候補遺伝子である。その観点から現在二つの染 色体が注目を集めている。

その第一は $\operatorname{IgE}$ 産生を誘発, 増加させるサイトカイ ン群（Th2型）であるIL-4とIL-13の存在する第 5 染色 体であり，第二はIgE産生を減少させるサイトカイン 群（Th1型）のIFN- $\gamma$ の存在する第12染色体である。

IL-4 promoter領域内にあるBsmFI多型を利用して関 連研究を行った報告はいくつかみられているが, 決 定的な結論は得られておらず，むしろ否定的である。

一方，第 12 染色体との連鎖が二つの人種で確認さ れているが, これらの結果は, アトピー集団でIgE抗 体の濃度が T 細胞のIFN- $\gamma$ 産生能と強く逆相関するの に対し, IL-4の産生能とは相関しないという機能的な 実験結果ともよく一致しており, 今後研究の主体は IL-4からIFN- $\gamma$ へと変わるものと考えられる。さらに この結果から, すでにIFN- $\gamma$ 遺伝子の筋肉注射や吸入 によるアトピーの治療法の研究がマウスで開始され ており, 今後の研究成果が期待されている。

現在のアトピー遺伝子解析の主流は, アトピーは Th1とTh2型サイトカインの分泌バランスの異常とと
らえる考えに基づいて，これらのサイトカイン遺伝 子やその受容体，さらには産生制御因子などに集中 している。

遺伝子本体の解明研究が進む中で, 人体の免疫ア レルギー組織に，実は重大な変化が起こりつつある ことが明らかにされつつある。人類は何百万年にも わたって, 細菌やウィルス, 寄生虫の脅威に曝され, その攻撃から逃れるシステムとして免疫機能を進化 させてきた。しかし，近年文明進化とともに急速に 環境の変化が進み, 多くの病原体が駆逐され; 病原 体防御機能（Th1）としての機能を失い, アレルギー 準備状態（Th2）へと大きく恋化しつつある。したが ってアトピー遺伝子の研究は, 環境と人類との共存 の研究であり，また人類進化の歴史への探究ともな りつつあって，環境やライフスタイルなどを含めた 人類の生態そのものをどのように変えていくかを真 剣に検討せねば，とうていアトピー疾患の予防は行 えないことを示している。

読者諸兄は試みに，アトピー患者におけるツベル クリン反応を調べてもらいたい。多くの患者が陰性 反応であると思われる。事実, 筆者らは, ツベルク リン反応の陽性度と血清中総 $\operatorname{IgE}$ との関係を予備的に 小学生について調査した。その結果, ツ反陰性反応 の児童ではIgE值が高く，Th2が優位であることを示 唆する結果を得た。このことは, Th2が優位であるこ とを示唆している。この反応をいかにしてTh1優位に 変えるかは, 治療, 予防の重要な課題であり, アト ピー候補遺伝子もこうした反応を制御していると考 えられ，この方面からのアプローチも期待される。

\section{N. ライフスタイルと染色体変異}

健康診断を受診した人々の中から 150 人に協力を求 


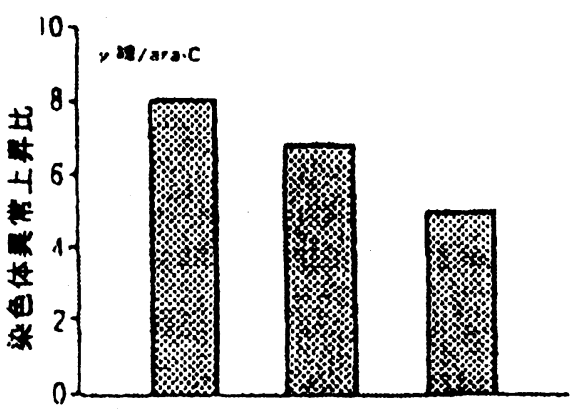

ライフスタィル

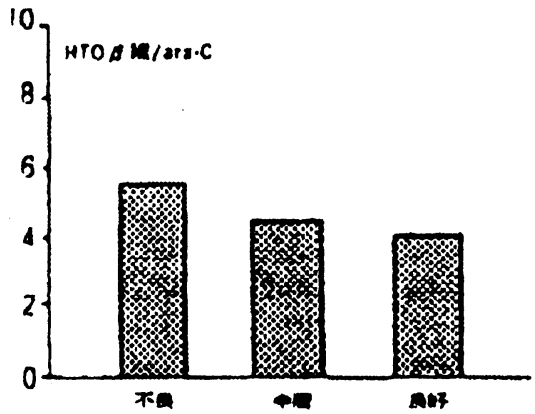

ライフスタイル

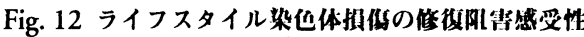

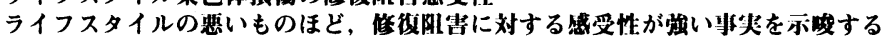

め，末梢血リンパ球を培養してライフスタイルとリ ンパ球染色体変異との関連性を調査した 20122)。

\section{1.ライフスタイルとSCE（姉妹染色分体交換）}

SCE（姉妹染色分体交換）については，自然発生 (base-line) 頻度，及び発がん物質に対する感受性を 検討する目的から，DNA傷害性物質である mitomycin-C (MMC) の一定量 ( $3 \times 10^{-8} \mathrm{M}$, 72時間処 理）による誘発頻度を検討した。その結果，ライフ スタイル良好群ほどSCE頻度が有意に低いことが明か となった。

また，SCE頻度への寄与が大きい3つの生活習慣 (喫煙, 飲酒, 自覚的ストレス量) について，このう ちいくつ守っているかで4群に分けたところ, やはり ライフスタイルの良いものほどSCE頻度が低かった22. 23)。

\section{2. ライフスタイルと染色体DNA損傷の復阻害感受性}

染色体の構造異常を指標にしてライフスタイルの 遺伝毒性的な影響を評価した。われわれが取った方 法は，放射線の一定線量（2Gy）により一定量の染色 体DNAの切断をまず生じさせる。これらの切断は, おのおののリンパ球中に存在する修復酵素により, 通常数十分以内にほとんどが再結合して修復するこ とが知られている。ところが，これらのうち，ある 切断端は元の通りに再結合せず, 誤って他の切断端 と再結合した結果，二動原体染色体や環状染色体が 生ずることが知られている。一方，これらの染色体 DNAの切断端の修復を阻害する物質として，コーヒ 一や日本茶の中に含まれるカフェイン, 重金属とし ての鉛やクロム，また，ガソリン中に含まれ大気污 染物質として問題となる発がん物質ベンゼン等が知 られている12)。また cytosine arabinoside（ara-C）は， 人間環境中には存在しないが, 染色体傷害の修復阻 害物質としてよく知られている薬剤である。そこで, 一定線量でリンパ球を照射しながら ara-Cで処理する ことにより，修復阻害に対する個々人のリンパ球の 感受性を観察した。
その結果，修復阻害剤であるara-C処理による染色 体構造異常頻度の上昇比は, 個人差がきわめて大き な事が判明した。ある個人については，ara-Cが共存 したために放射線誘発染色体構造異常頻度は10倍以 上に増幅される一方，ある集団では，同濃度のara-C の共存下での, 同線量の放射線暴露にもかかわらず, ほとんど染色体異常頻度の増幅が見られない結果と なった。そこで，これら10倍近い染色体異常の上昇 比の差異をもたらす要因として，血液提供者のライ フスタイルを考え，図 1 に述べた健康習慣指数で対 象者を 3 群に分け（これらライフスタイルの良好. 中庸・不良群のそれぞれの平均年齢は $46.2 \pm 7.2$,

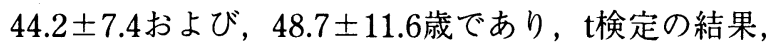
有意差は見られなかった)，各集団ごとに染色体異常 上昇比を見たところ，図 12 に示すごとく，ライフス タイル不良な集団（図 1 に述べた健康習慣のうち, 守っている数の少ないもの) ほどara-C処理による染 色体構造異常頻度の上昇比が大きかった ${ }^{24)}$ 。

\section{3. 喫煙による染色体変異の誘発}

ライフスタイル環境のうち, 喫煙, 飲酒, ストレ スが特にSCE誘発に多大の寄与をする事実から, まず, 煙草の煙から国際的な標準法によりタールを捕集し, それらを異なる濃度で試験管内でリンパ球に処理し, 誘発される染色体変異 (SCE) を観察した。その結果, $100 \mathrm{mg} / \mathrm{ml}$ 以上の濃度でタバコタールを処理した場 合，リンパ球に染色体変異が誘発される事実が明か となった。また，すでに我々は勤務時間中，常に高 濃度の夕バコ煙に間接的に暴露している喫茶店従業 員 (非喫煙者) の末梢リンパ球における染色体変異 の調査研究から，特にこれら間接的にタバコ煙に暴 露して働いている人々のリンパ球は, 発癌物質に暴 露した際に誘発される染色体変異量が，夕バコ煙非 曝露者のリンパ球に比し有意に高い事実を報告して いた。それらの事実と合わせ，この夕バコ煙による 直接的な染色体変異の誘発を示す事実は, ライフス タイルの中でも契煙が大きな不健康行動である事実 を染色体変異を指標として確認したことになる ${ }^{22,241}$ 。 


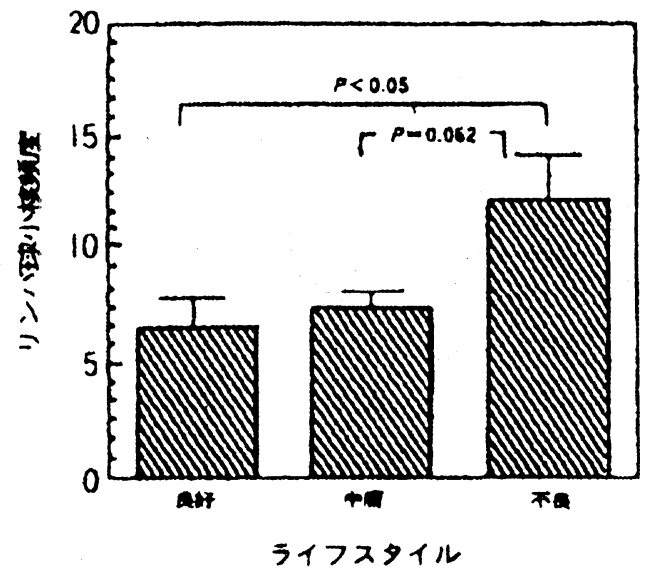

Fig. 13 ライフスタイルと架他体変哄 (小核斯度)

\section{4. ライフスタイルと小核形成}

人体内に誘発された染色体構造異常と染色体数的 異常の簡便な指標として注目されている末梢リンパ 球における小核形成頻度を指標に，ライフスタイル の影響を検討した。すでに述べたと同様に, 個々人 がを守っている健康習慣の数で 3 群対象者を分けた。 それぞれの群のリンパ球における小核頻度を見たと ころ, 特にライフスタイルの不良群は有意に高い小 核頻度を有していた（図13）。これらライフスタイル による 3 群間の差から, 包括的な日常生活習慣がリ ンパ球小核頻度に影響を及ほしたものと考えられる。 日常生活習慣の個々の要因がリンパ球小核頻度にど の程度寄与しているかを解析したところ, SCE誘発に 大きく関与する喫煙, 飲酒, ストレス感とは異なり, 運動習慣, 喫煙および睡眠時間がほぼ同様に重要な 寄与をしめすことが明らかとなった。

\section{5. 遺伝素因によるアルコール誘発染色体変異の変化}

喫煙についで染色体変異誘発への寄与の高い飲酒 に注目する。特に我々日本人（モンゴロイド）の半 数がアルデヒド脱水素酵素アイソザイム 2 が遺伝的 に欠損しているために，アルコールが肝で代謝され てできるアセトアルデヒドによって誘発される染色 体変異（SCE）が高いのではないかと疑われる。そこ で, アルコールパッチテスト, 飲酒後の酪酊症状の 調査（TAST），およびPCR法による遺伝子増幅手法を 用い, 個々人のアルコール感受性を表現型と遺伝子 型の双方において同定した25-28)。その結果, 表 6 にみ
られるごとく ALDH2が遺伝的に欠損しているにもか かわらず毎日飲酒をしている群はそれ以外の群に比 し，染色体変異が有意に高い事実が明かとなった。

毎日の飲酒量による染色体变異の誘発を見た場合, 自然誘発SCE頻度ならびにハイドロキノン（OH基を 2 つ持つベンゼン代謝物で発がん性が疑われている 物質）に上る誘発SCE頻度ともにALDH2の欠損群の みに，飲酒量に応じて染色体変異（SCE）の上昇が観 察された。

近年, 酸化的DNA損傷が老化あるいは発がん危険 度の重要な指標として近年注目されている。演者ら は, 健康な集団の末梢リンパ球中に生じた酸化的 DNA損傷 (8-OHdG) 量を無酸素状態でのDNA抽出 法を開発して測定した。その結果, 特にALDH2の変 異型遺伝子を持つ集団のリンパ球において, 飲酒量 に応じた酸化的DNA損傷の有意な上昇が観察された 29)。

以上の結果から, 健康習慣としてライフスタイル を見た場合に，ライフスタイルの良い集団ほど染色 体の变化 (SCE頻度, 放射線誘発染色体DNA切断の 修復阻害作用に対する感受性，小核形成，および酸 化的DNA損傷（8-OHdG））が低かった。

\section{V. ライフスタイルとストレス}

「ストレスは人生のスパイスである」と看破した のは，かのハンス・セリエであるが，ストレスは， 我々人間が有意義な人生を送るために必須のもので ある ${ }^{310}$ 。しかるに，わが国に代表されるような緊張感 にあふれ，集約的な労働を余儀なくさせる現代の高 度管理社会の中では, 個々人の持つストレス耐性を 上回る精神心理的ストレッサー（ストレイン）が負 荷され, 多くのメンタルヘルス上の問題を生んでい る 30-34)。産業ストレス研究の課題は, このような複雑 な社会構造の中で生ずる, 極めて把握しにくいスト レッサーーストレス反応を科学的かつ人間的な視点 からえぐり出し, その解決の方向を明確に示唆する ところに存在すると言ってよい。

本論では, これらストレッサーーストレス反応の 科学的関係性を定量的に把握し, さらにその労働に 対する意味論を含めて論じてみたい。すなわち，ス トレス反応は個体差が極めて大きくかつ経時的にダ イナミックに変動するものである事実を考慮にいれ

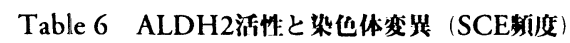

\begin{tabular}{|c|c|c|c|c|c|c|}
\hline \multirow{2}{*}{ 飲 酒 } & \multicolumn{2}{|c|}{ ALDH-2 (パッチテスト) } & & \multicolumn{2}{|c|}{ ALDH-2 (TAST) } & \\
\hline & $(+)$ & $(-)$ & & $(+)$ & $(-)$ & \\
\hline 揜: $\mathrm{B}$ & $10.29 \pm 1.61$ & $11.44 \pm 1.99$ & & $10.18 \pm 1.37$ & $11.44 \pm 1.98$ & \\
\hline & $\mathrm{n}=36$ & $\mathrm{n}=21$ & $p=0.020$ & $\mathrm{n}=41$ & $n=26$ & $p=0.007$ \\
\hline 週数回 & $10.14 \pm 1.41$ & $9.92 \pm 1.55$ & & $10.08 \pm 1.83$ & $10.04 \pm 1.45$ & \\
\hline 领酒せず & $\begin{array}{c}n=18 \\
p=0.739\end{array}$ & $\begin{array}{c}n=34 \\
p=0.003\end{array}$ & $p=0.630$ & $\begin{array}{c}n=18 \\
p=0.0820\end{array}$ & $\begin{array}{c}\mathrm{n}=41 \\
\mathrm{p}=0.001\end{array}$ & $\mathrm{p}=0.913$ \\
\hline
\end{tabular}

t検查. 
日衛誌（Jpn. J. Hyg.）第54巻 第 4 号 2000年 1 月

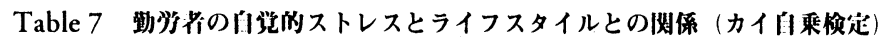

\begin{tabular}{|c|c|c|c|c|}
\hline \multirow{2}{*}{ ライフスタイル要因 } & \multicolumn{3}{|c|}{ 自覚的ストレス } & \multirow{2}{*}{ カイ自乗值 } \\
\hline & 多い & 普通 & 少ない & \\
\hline 多忙感: & $58.3 \%(423)$ & $32.3 \%(415)$ & $25.8 \%(31)$ & $141.5858^{* *}$ \\
\hline 体調患化 & $26.2 \%(190)$ & $8.6 \%(111)$ & $3.3 \%(4)$ & $128.93^{* *}$ \\
\hline 何:日の生活に不満) & $86.4 \%(627)$ & $71.2 \%(916)$ & $52.5 \%(63)$ & $92.85^{* *}$ \\
\hline 9 時䦌以上の学働歭間 & $70.0 \% \quad(508)$ & $55.6 \%(715)$ & $49.2 \% \quad(59)$ & $46.37^{* *}$ \\
\hline 不規則な生活 & $26.6 \%(193)$ & $16.6 \%(213)$ & $15.0 \%(18)$ & $31.15^{* *}$ \\
\hline 不规則な食事 & $32.8 \%(238)$ & $21.8 \%(280)$ & $22.5 \%(27)$ & $30.19^{* *}$ \\
\hline 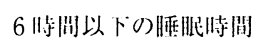 & $40.9 \% \quad(297)$ & $31.8 \%(409)$ & $27.5 \%(33)$ & $19.87^{* *}$ \\
\hline 间食 & $53.3 \%(387)$ & $57.4 \%(738)$ & $44.2 \%(53)$ & $9.45^{*}$ \\
\hline コーヒー・紅茶() & $12.0 \%(87)$ & $8.2 \%(106)$ & $12.5 \%(15)$ & $8.46^{*}$ \\
\hline 胡食 & $23.8 \%(173)$ & $20.0 \%(257)$ & $23.3 \%(28)$ & NS \\
\hline 㩦分をひかえない & $49.9 \%(362)$ & $50.4 \%(648)$ & $59.2 \%(71)$ & NS \\
\hline
\end{tabular}

a)「いうも忙しい」と答えた物の制合を示す。

b) 6 カ下筒前と比輅して，身体の調子が悪くなったと思う者の割合を示す。

c)「留[の生活に満足していますか？」という質問に対し，「いいえ」または「少し」と答えた者の割合を示す。

d) コーヒーや紅茶を一日 5 怀以上领む者の割合を示す。

c) 胡食を食べない者の㓶合を示す。

${ }^{*} \mathrm{p}<0.01,{ }^{* *} \mathrm{p}<0.0001$

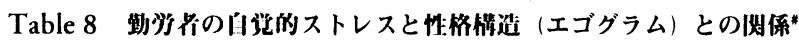

\begin{tabular}{|c|c|c|c|c|}
\hline \multirow{2}{*}{ 性:格装何 } & \multicolumn{3}{|c|}{ 自覚的ストレス } & \multirow{2}{*}{ カイ自乘 } \\
\hline & 多い & 普通 & 少ない & \\
\hline \multicolumn{5}{|c|}{ Critical Parent: } \\
\hline 完全主我 & $47.9 \%(348)$ & $35.9 \%(462)$ & $38.3 \%(46)$ & $28.02^{* * *}$ \\
\hline 幐父 & $45.9 \%$ & $40.7 \%$ & $50.8 \%(61)$ & $8.29^{*}$ \\
\hline \multicolumn{5}{|c|}{ Nurturing Parent: } \\
\hline 視切 & $62.3 \%(452)$ & $60.8 \%(782)$ & $60.0 \%(72)$ & NS \\
\hline 䆓突 & $54.0 \%(392)$ & $53.3 \%(686)$ & $54.2 \%(65)$ & NS \\
\hline \multicolumn{5}{|l|}{ Adult: } \\
\hline 理性啲 & $64.6 \%(469)$ & $59.8 \%(769)$ & $57.5 \%(69)$ & NS \\
\hline 合埋的 & $56.5 \%(410)$ & $53.8 \%(692)$ & $57.5 \%(69)$ & NS \\
\hline \multicolumn{5}{|l|}{ Free Child: } \\
\hline 町约 & $42.8 \%(311)$ & $43.9 \%(565)$ & $59.2 \%(71)$ & $11.43^{* *}$ \\
\hline 自発的 & $42.4 \%$ & $40.2 \%$ & $44.2 \%(53)$ & NS \\
\hline \multicolumn{5}{|c|}{ Adapted Child: } \\
\hline 神経犋 & $61.0 \%(443)$ & $40.8 \%(525)$ & $25.0 \%(30)$ & $100.3^{* * *}$ \\
\hline 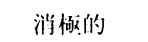 & $31.3 \% \quad(227)$ & $28.5 \%(366)$ & $18.3 \%(22)$ & $8.63^{*}$ \\
\hline
\end{tabular}

\#性格の要素がどの程度あるかを䦌う質閵で，「かなりある」または「大変ある」と答えた者の制令を示す。

${ }^{*} \mathrm{p}<0.05,{ }^{* *} \mathrm{p}<0.005,{ }^{* * *} \mathrm{p}<0.001$

ながら，それを精神心理的な手法ならびに医科学的 な実験手法で定量的に評価把握し，Quality of Life （QOL）あるいはQuality of Working Life（QWL）と の係わりについて考察する。

\section{1.ストレッサー評価}

本研究では某事業所の従業員を対象に労働安全衛 生法に定められた健康測定時に血液生化学的検査, 尿検査，血圧測定を行い，同時にいくつかの質問用 紙に記入してもらい必要に応じて産業医あるいは保 健婦による面接を行った ${ }^{35)}$ 。用いたストレッサー評価 尺度は日常生活出来事 (Life Event, ホームズとラーエ, 1967），日常苛立ち事尺度（Daily Hassles，ラザルス、 1983）ならびにライフスタイルとしての主観的スト レス感（森本 1987）である。8つの健康習慣とし
ての主観的ストレス感については自覚的なストレス 量の大きさについて 3 段階（過㮃，適度，過少）で 評価した ${ }^{36-39) 。 ~}$

\section{2. 主観的ストレス感}

ストレッサー評価尺度のうち，「主観的ストレス感」 はストレッサーに対する個々人の感受性をも加味し た優れた指標と考えられ，その意味では，次に述べ るストレス反応評価尺度としての質も有する。また, これらの主観的なストレス感はLife EventやDaily Hasslesで評価したストレッサーと良い相関を示す。 これら主観的なストレス感は種々のライフスタイル 要因と関連性を示す（表 7 )。

特に, 多忙感, 体調の変化, 生活に対する不満, 長時間労働, 不規則な生活, 睡眠不足, コーヒー。 
紅茶などの摂取量と有意な相関を示す。また，交流 分析手法で $5 つ$ 構造軸にわけたそれぞれの性格構 造との係わりを検討したところ, 完全主義や明朗な 子どもらしさ，あるいは神経質な性格などと強い関 連性を示すことが明かとなった（表 8$)^{38-41) 。 ~}$

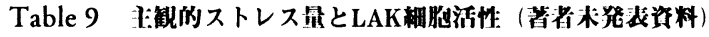

\begin{tabular}{|c|c|c|c|c|c|}
\hline \multirow[t]{2}{*}{ 神経的ストレス } & \multicolumn{3}{|c|}{ LAK activity (\%) } & \multirow[t]{2}{*}{ LUs/10'cells } & \multirow{2}{*}{$\begin{array}{l}\text { Relative } \\
\text { effect }\end{array}$} \\
\hline & $20: 1$ & $10: 1$ & $5: 1$ & & \\
\hline $\begin{array}{l}\text { 普通または }(\mathrm{n}=37) \\
\text { 少ない }\end{array}$ & $85.9 \pm 12.8$ & $75.5 \pm 17.6$ & $53.2 \pm 18.7$ & 505.8 & 1.46 \\
\hline$(n=17)$ & $78.4 \pm 15.5$ & $65.9 \pm 19.3$ & $45.1 \pm 19.7$ & 346.3 & \\
\hline
\end{tabular}

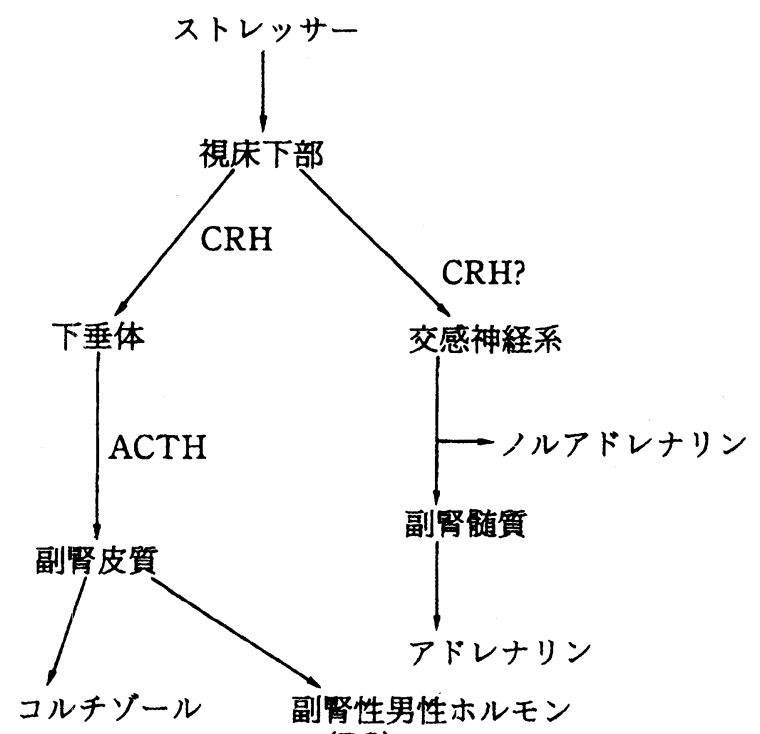

(DS)

ストレス時の下垂体一副腎皮質系と交感神経一副腎铕 買系の反応

DS: Dehydroepiandrosterone sulfate

CRE: Corticotropin Releasing Hormone

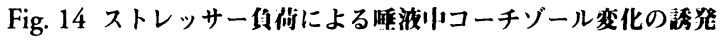

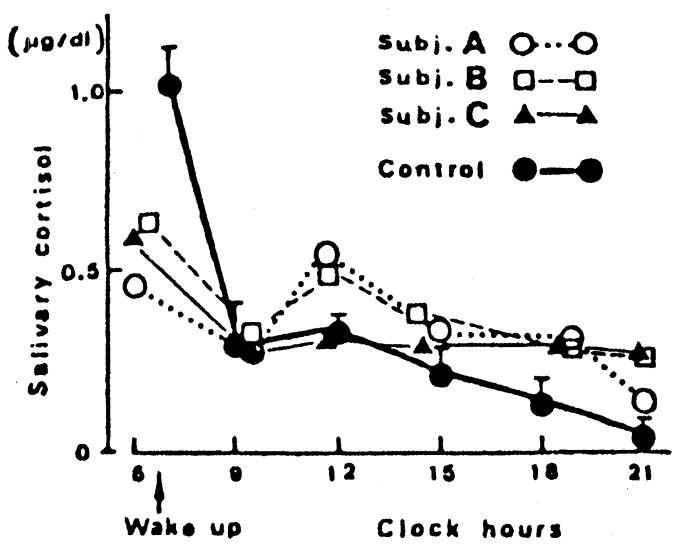

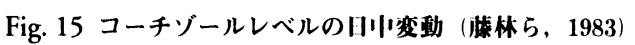

\section{3.ストレス反応評価}

\section{3-1 内分泌学的ストレス反応}

ストレッサー負荷により下垂体からACTHが分泌さ れ，副腎皮質ホルモン（コーチゾール）レベルが上 昇することがよく知られている。血中に分泌された これらコーチゾールは, 尿中あるいは唾液中のコー チゾールレベルにも反映する。そこで我々は職域に 応用できる点を考慮して, 唾液中コーチゾールレベ ルの変化を生理的ストレス反応の指標として測定し た（図14）。唾液のサンプリングは起床直後，午前10 時30分，14時30分，ならびに15時の 4 点で行った。 通常唾液中コーチゾールレベルは起床直後に高く, 起床後活動を開始すると共に急速に低下する（図15）。 しかるにストレッサー負荷が強い（Daily Hassles得 点で 2 点以上）場合には起床時の唾液中コーチゾー ルレベルの上昇が比較的低い一方, 起床後の活動を 開始した場合でもコーチゾールレベルの低下が緩慢 であった（図16）。ちなみにこのような変化は高齢者 にみられるコーチゾールレベルのサーカディアンリ ズムの変化に対応しているものと思われる（図 2 , 3 )。その意味ではストレッサー負荷により精神的活 動が高齢者のそれにシフトしているとも解釈できる 興味ある結果となった。

\section{3ー2 ストレスによる免疫学的防御機構の破綻 (がん免疫力の変動)}

Psycho-Neuro-Immunology（PNI）分野の研究が近 年著しい発展を遂げている。これは精神心理的な負 荷反応と神経科学的反応, ならびに免疫学的反応の 3 者が有機的かつダイナミックに相互連関し, 作動 している生体維持防御機構が急速に解明されつつあ る現状を示している。ストレス科学研究分野でもこ れら 3 者の関係を同時的に定量的に把握する必要が 生じている。社会心理的なストレッサーが脳内分泌 系を大きく変動させ，先に述べたようなコーチゾー

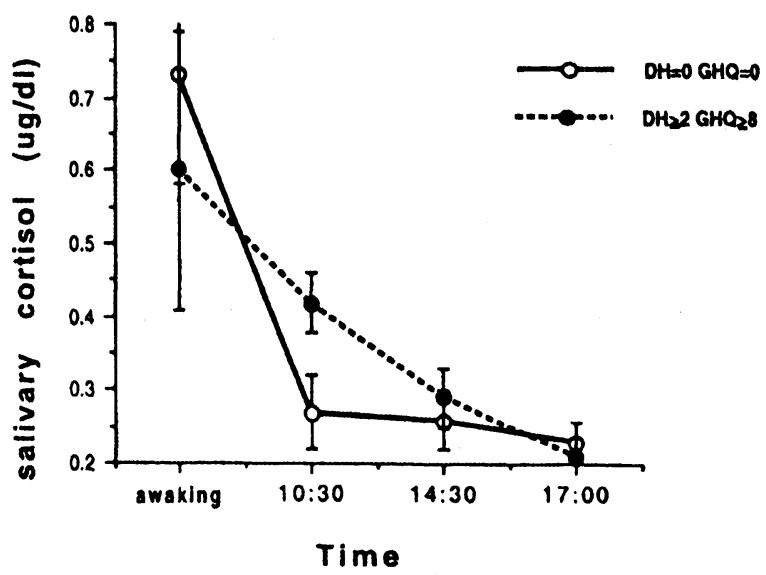

Fig. 16 ストレッサー分㫦によるコーチゾールレベルの帘化 (者者木発数料) 


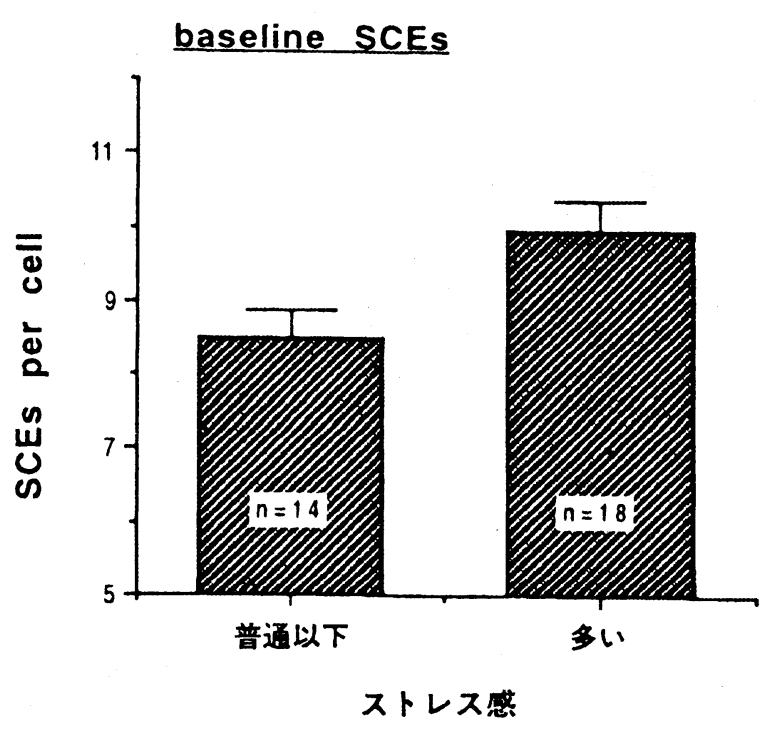

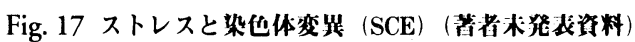

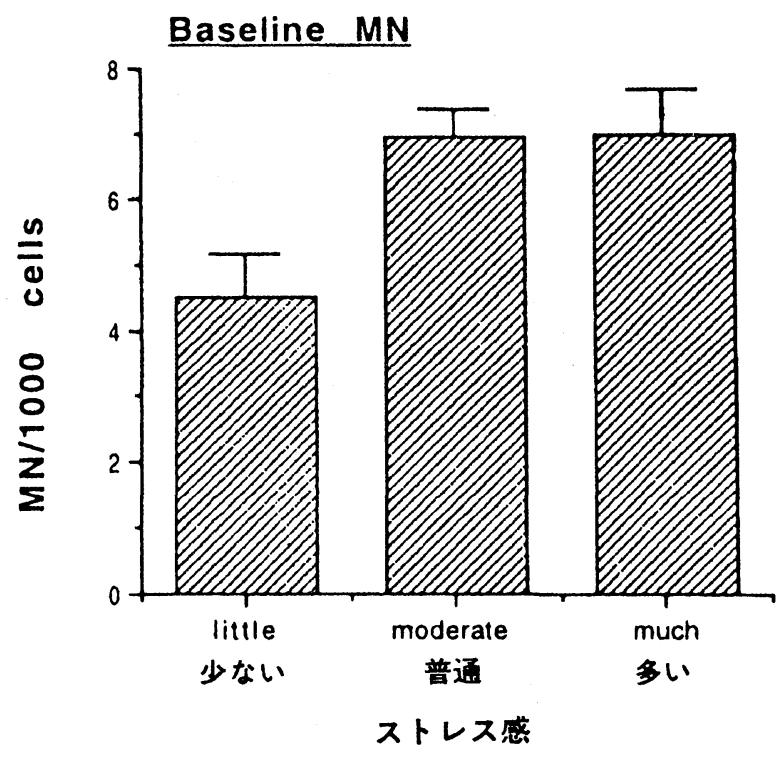

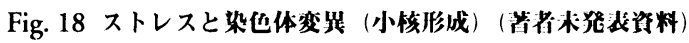

ルレベルでその変動が評価される一方，末梢・中枢 神経系にも影響を及ぼすと共にがん免疫力（NK細胞 活性）などの重要な生命維持機能二生体防御機構に も多大の影響を及ぼす事実が知られている。ストレ ス反応の中でもこれらの免疫系反応は健康破綻との 関連性が深い防御機構を擋乱するという点で, 産業 保健上, 高い指標性を有する。しかるに従来のメン タルヘルス＝ストレス健康管理体系の中では，指標 として取り上げられることがほとんどなかったと言 える。

筆者らはライフスタイル健康習慣を包括的に評価 する一方，ナチュラルキラー活性（がん免疫力）が ストレッサー負荷によりいかに変動するかを産業現 場で測定した。ナチュラルキラー（NK）細胞活性は
通常のクロム51遊離法を用い，エフェクター細胞に 対するターゲット細胞の比は $5 ， 10 ， 20 に$ 定めた。

これらのET比のいずれにおいても，主観的ストレ スの多い者はそうでないものに比較して約 $40 \%$ NK活 性が低いことが判明した 8 ,37-40)。

さらに最近ではLymphokine Activated Killer cell活 性が腫瘍に羅患した場合に誘発されるがん免疫力と して注目されている。これら潜在的ながん免疫力を 測定する目的でIL2で処理した際に誘発されるLAK細 胞活性を測定した。その結果 N K 活性と同様にLAK活 性も自覚的なストレス感の高い集団は $46 \%$ 低い值を 示した (表 9 )。

これらの結果は末梢リンパ球染色体変異 20, 22, 23.401411 が主観的ストレス量の多い集団に高い事実と考え合 わせると，ストレス負荷の多い群にはより多くのが ん細胞が発生する危険性が高く（Initiationが大きい）， 同時にそれらの遺伝子的にがん化した細胞がさらに 増殖していく危険性も高いものと考えられる

\section{3-3 ストレスと染色体遺伝子変異}

我々の末梢血球中の染色体遺伝子は容易に採取で きる人体試料としての予防医学上重要な位置を占め る 20, 25, 41,42)。特に私どもは，末梢りンパ球中の染色体 変異（姉妹染色分体交換 (SCE), 染色体構造異常あ るいは小核形成 $(\mathrm{MN}))$ が契煙，労働時間，睡眠時 間あるいはストレス感などの包括的ライフスタイル と有意に関連している事実を報告してきた。例えば， 主観的ストレス感が末梢リンパ球染色体変異 (SCE, MN）頻度に及ぼす影響は顕著である（図17，18）。 さらに染色体を構成しているDNA Double Strandsそ のものにおける遺伝子損傷を定量的に測定する手法 を開発し8.20, 22, 23, 25,37-47)，中でも酸化的DNA損傷として, 突然変異誘発とも強い関連性を示す 8 ーヒドロキシ グアニン形成量をストレス感との関連で計測した (図19)。この 8 -ヒドロキシグアニン量をストレス

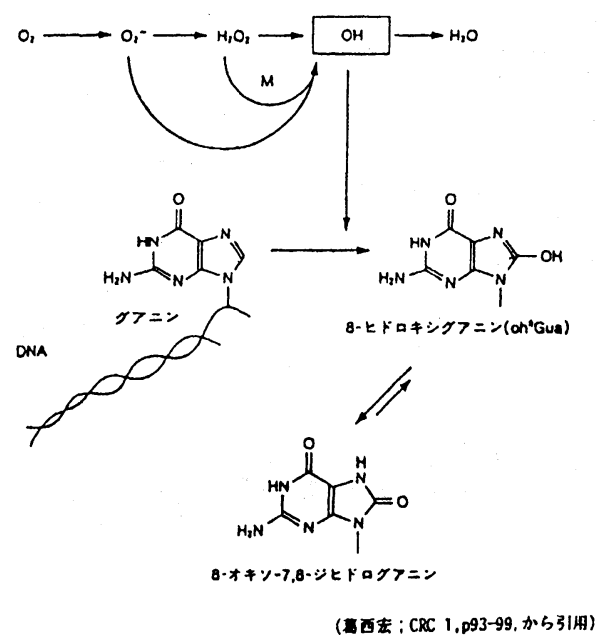

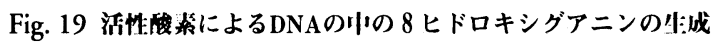




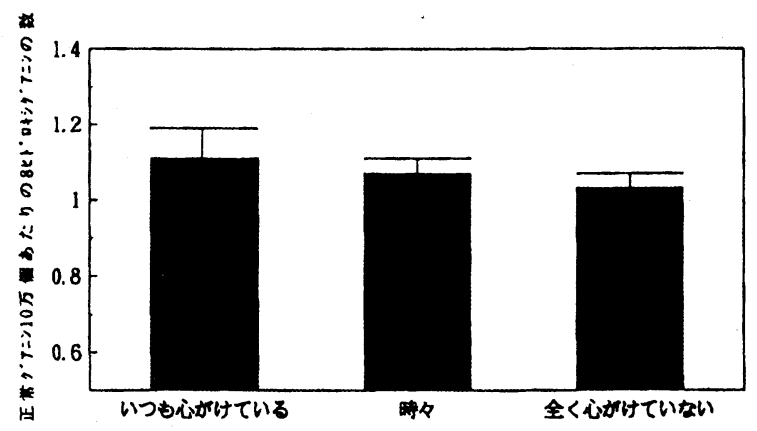

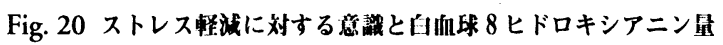
(者者林発丧资料)

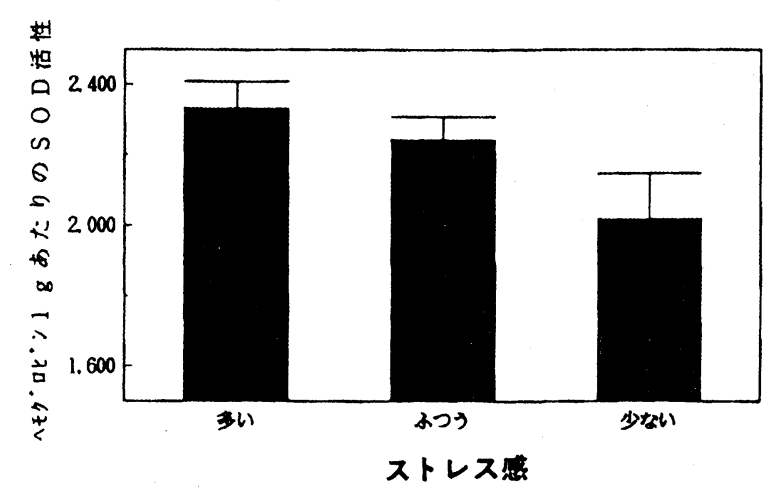

Fig. 21 自翼的ストレス量と赤血球SOD活性

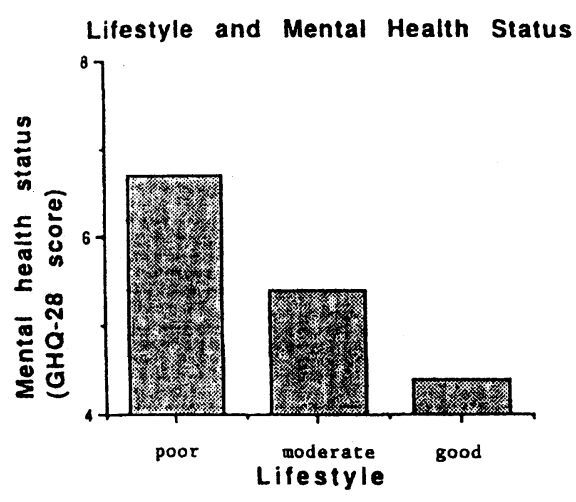

Fig. 22 ライフスタイルとGHQ28

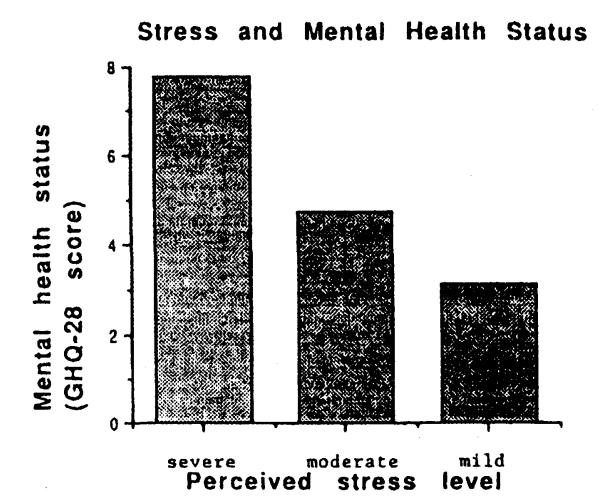

Fig. 23 主制的ストレス热とGHQ28

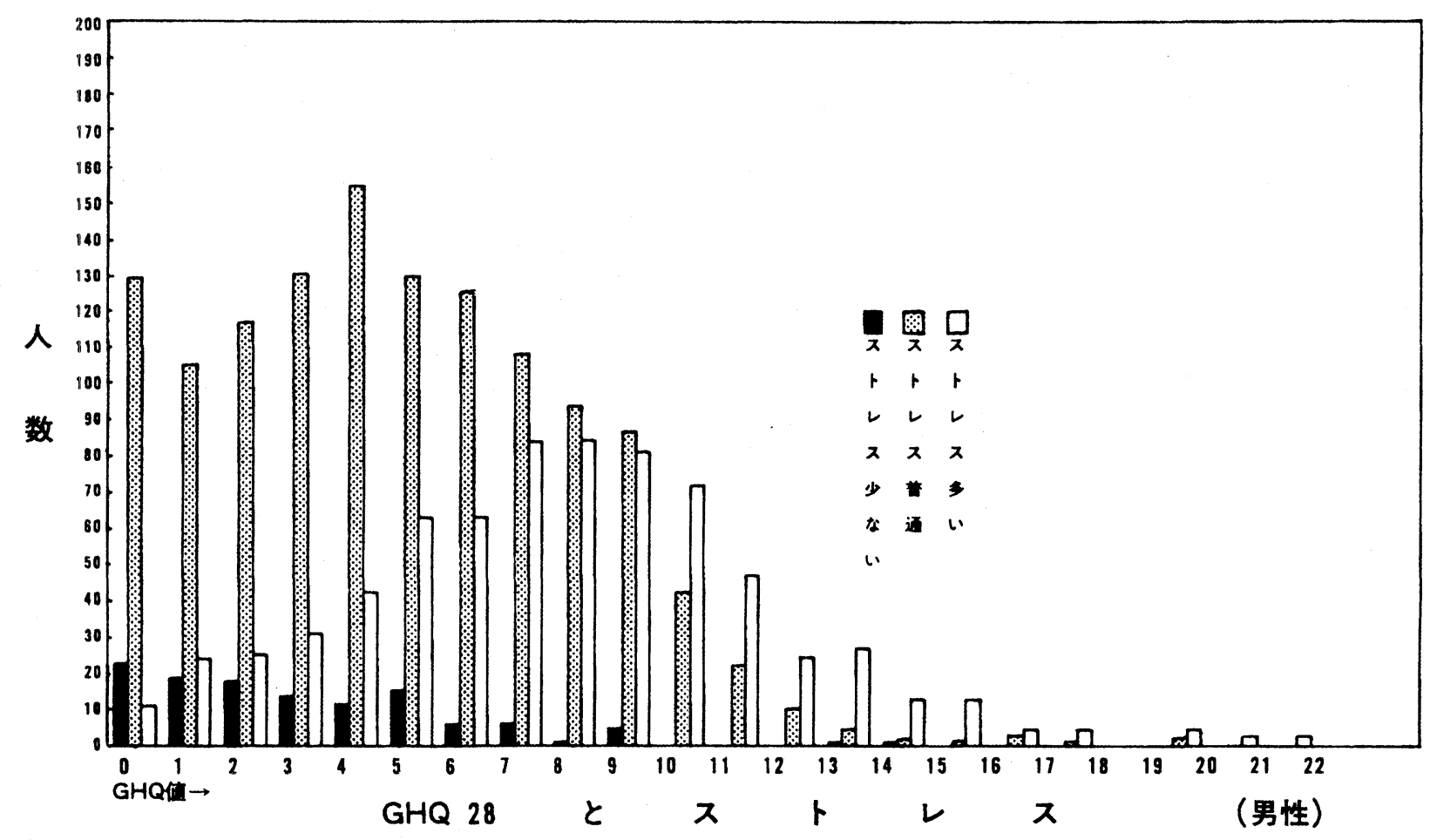

Fig. 24 GHQ28とストレス反心の佃人涇 
軽減に対する意識（ストレスコーピング量）との関 連で見たところ，図20のごとく興味ある結果を示し た。これら酸化的染色体DNA損傷の原因になる活性 酸素は，SOD（スーパーオキシドジスム夕ーゼ）に より除去されることがよく知られている。そこで, 自覚的ストレス量と赤血球中SOD活性との関連を見 たところ図21に見られるごとく，自覚的ストレス感 の多い人の赤血球中SOD活性は高い結果を示した。 これらの結果はヒト染色体DNA損傷の中で重要な位 置を占める活性酸素障害がストレス並びにストレス コーピングと何らかの関連性を持っている事実を示 唆しており，興味のもたれるところである。しかし， これらの作用機構については全く知見がなく，これ からの研究課題と考えられる。

\section{3-4 General Health Questionnaire (GHQ28)に よるストレス反応評価 ${ }^{33,48-51)}$}

ストレス反応を質問紙法によりReliability（信頼性） やValidity（妥当性）を評価する試みが数多くなされ てきた。中でもGHQ28は各国で広く用いられると共 にその信頼性や妥当性についても種々の文化圈でよ く検討されてきた ${ }^{38.39}$ 。また，GHQ28を構成する28項 目は, 身体的症状, 不安と不眠, 社会的活動障害打 よび重度のうつ状態の 4 つの軸から構成され，それ

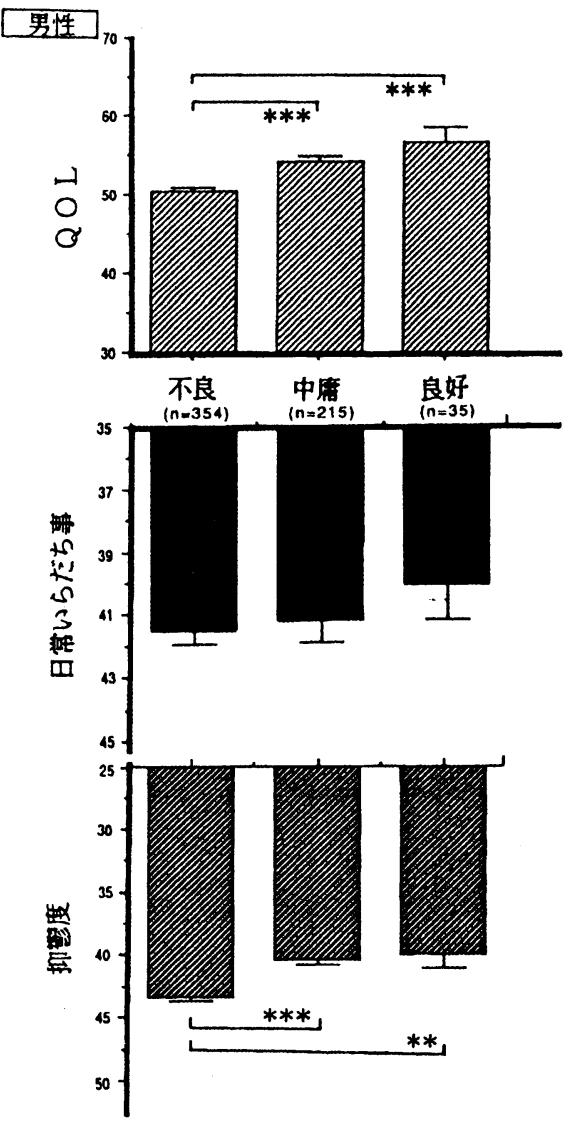

Fig. 25 ライフスタイル则によたQOLと日常いらだち求・抑うつ度
ぞれの軸の持つ精神保健学上の意義もよく検討され ている。まず，包括的なライフスタイルとGHQ28と の関係を職域で検討したところ，予想されたごとく ライフスタイルの悪い集団は有意に高いGHQ28得点 を示し, 精神 - 心理的健康度の低下が強く示唆され た（図22）。また，主観的ストレス量の高い集団の $\mathrm{GHQ} 28$ 得点は, ストレス感の少ないものの平均で 2.5 倍の高さを示し，主観的ストレス感はこれら GHQ28 で評価される精神的健康状態と強い関連性を持つこ とが示された（図23）。なお，これらGHQ28を構成す る 4 つの軸についてもほぼ同様の主観的ストレス感 との関連性が見られた。

ところで，このような平均值の議論も勿論重要で あるが，ストレス反応の個人差も重要な要因として 注目されている。そこで主観的ストレス感により 3 群に分け，それぞれのGHQ28得点の分布を見たとこ ろ，図24のごとく興味ある結果となった。すなわち， ストレス感の少ないものでも高いGHQ得点を示すも のが少数存在する一方，ストレス感の多い集団の中 にもGHQ28得点が極めて低いものが存在する。これ ら個人間のストレス反応感受性の差違がいかなる機 作で招来されるか興味のもたれるところであり，今 後の重要な検討課題である。

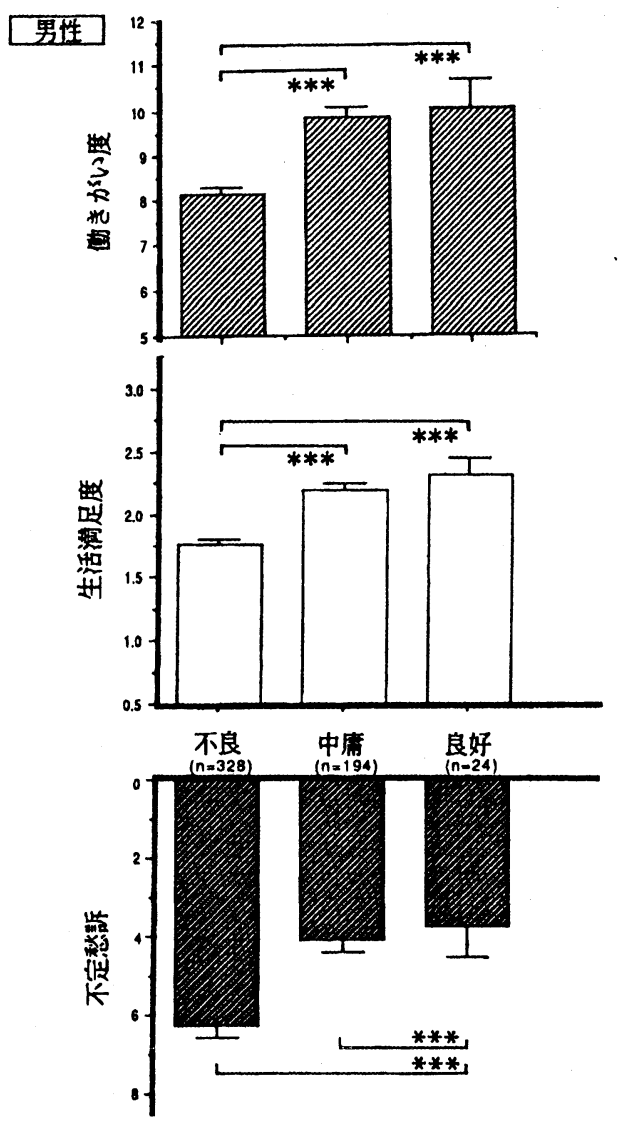

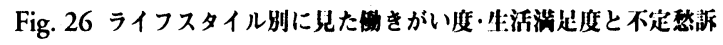




\section{4. ストレスと Job Satisfaction}

さまざまなストレッサー負荷あるいはストレス感 と, 生活満足度, あるいは働きがい感（Job Satisfaction）とはいかなる関係にあるのか。まずわれ われはライフスタイル（8つの健康習慣指数から 3 群に層別化) と, Quality of Life (QOL), ストレッサ 一負荷としての日常いらだち事，およびストレス反 応としての抑うつ度の関連をみたところ（図25）, 明 らかにライフスタイルの良好な群ほどQOLは高く， 日常いらだち事や抑うつ度は低かった。次に，働き がい感ならびに生活満足度および不定愁訴とライフ スタイルとの関連を見たところ（図26），包括的ライ フスタイルの良好なものほど働きがい感, 生活満足 度とも高く，不定愁訴は少なかった。

次にストレッサーとしての日常いらだち事と生活 満足度ならびに㗢きがい感との関連を見たところ, 男女とも日常いらだち事で評価したストレッサーの 多いものほど生活満足度や働きがい感が低かった。 主観的なストレス感とこれら Job Satisfactionとの関連 についても, ストレス感の多いものほど満足度は男 女とも低かった。また，ストレス反応として抑うつ 度をZungのSDSで評価し, 生活満足度及び働きがい 感との関連を見たが，これらの結果においても男女 とも同様の結果を示した。

以上，ストレッサー負荷が多く，ストレス反応の 強く出る集団は生活満足度（Quality of Life）や働き がい感（Job Satisfaction）も低く出ることが示された。 また，ストレッサーは抑うつ度や不定愁訴などの精 神心理的な不健康反応のみならず, 個々人の染色体 遺伝子の変異量にまで定量的な影響を及ぼすことが 示された。

精神的健康度は, 種々の包括的なストレス関連指 標を個人並びに集団のレベルで精度高く評価しなが ら, 個人の感受性（性格行動特性など）による大き な個体差を十分考慮にいれながら評価し, 実際の保 健活動に活用していく必要があろう。

\section{文 献}

1) 森本兼粪. ライフスタイルと健康. 東京: 医学書 院, 1991.

2) Sobel ME. Life-style and Social Structure. New York: Academic Press, 1981.

3) 渡辺 潤. ライフスタイルの社会学., 東京: 世界 思想社, 1982.

4) Berkman LF, Breslow L. Health and Ways of Living. New York: Oxford University Press 1983.

5) Hagihara A, Morimoto K. Personal health practice and attitudes toward non-smokers' legal rights in Japan. Soc. Sci. Med. $1991 ; 33$ : 717-21.

6) Ezoe S, Morimoto K. Behavioral lifestyle and mental health status of Japanese factory workers. Prev. Med. 1994 ; 23 : 98-105.

7) Belloc NB, Breslow L. Relationship of physical health status and health practices. Prev. Med. $1972 ; 1: 409-21$.

8) Kusaka Y, Kondo H, Morimoto K. Healthy lifestyles are associated with higher natural killer cell activity. Prev. Med.1992 ; 21 : 602-15.

9) Inoue $\mathrm{C}$, Morimoto $\mathrm{K}$, et al. Healthy lifestyles are associated with higher lymphokine-activated killer cell activity. Prev. Med. 1996 ; 25 : 717-24.

10) Shirakawa T, Morimoto K. Lifestyle effect on total IgE. Lifestyles have acumulative impact on controlling total IgE levels. Allergy $1991 ; 46: 561-9$.

11) Shirakawa T, Kusaka $Y$, Morimoto K. Specific IgE antibodies to nickel in workers with known reactivity to cobalt. Clin. Exp. Allergy $1992 ; 22$ : 213-8.

12) Shirakawa T, Morimoto K. Effect of lifestyle on levels of specific IgE antibodies. Allergy 1993 ; $48: 177-82$.

13) Shirakawa T, Morimoto $K$, et al. Association of life style with high risk of hyperimmunity and of immunosuppression mediated by IgE. J. Clin. Epidemiol. 1996 ; 49 : 1059-65.

14) Shirakawa T, Morimoto $K$, et al. Effect of maternal lifestyle on cord blood IgE factor. Eur. J. Epidemiol. $1997 ; 13: 395-402$.

15) Shirakawa $T$, Morimoto $K$, et al. Linkage between severe atopy and chromosome 11q13 in Japanese families. Clin. Genet. 1994 ; 46 : 228-32.

16) Mao X-Q, Morimoto $K$, et al. Association between genetic variants of mast-cell chymase and eczema. Lancet $1996 ; 348: 581-3$.

17) Shirakawa $T$, Morimoto $K$, et al. Association between Fc $\varepsilon \mathrm{RI} \beta$ and atopic disorder in a Japanese population. Lancet $1996 ; 347: 394-5$.

18) Shirakawa T, Morimoto K, et al. Associaiton between atopic asthma and a coding variant of $\mathrm{Fc} \varepsilon$ RI $\beta$ in a Japanese population. Hum. Mol. Genet. $1996 ; 5: 1129-30$.

19) Mao $X-Q$, Morimoto $K$, et al. Association between serotonin type 2 receptor (HTR2) and bronchial asthma in humans. J. Med. Genet.1996 ; $33: 525$.

20) Morimoto K, Wolff S. Cell cycle kinetics in human lymphocyte cultures. Nature $1980 ; 288: 604-6$.

21) Morimoto K, Sato M, Koizumi A. Proliferative kinetics of human lymphocytes in culture measured by autoradiography and sister chromatid differential staining. Exp. Cell Res. 1983 ; 145 : 349-56. 
22) Morimoto K. Life-style and Genetic Factors that Determine the Susceptibility to Production of Chromosome damage. In: Obe, G. and Natarajan, A. T.(eds.): Chromosomal Aberrations: Basic and Applied Aspects. Springer-Verlag, Berlin, 1990 : 287-301.

23) Tice R, Morimoto K, et al. Sister Chromatid Exchanges. New York: Plenum Press, 1984.

24) Morimoto K.Life-style, Health and quality of life. WHO Inter national Conference on Health Promotion Document. Jeneva: Ottawa. WHO., 1986.

25) Takeshita T, Morimoto K, et al. Phenotypic differences in low $\mathrm{Km}$ aldehyde dehydrogenase in Japanese workers. Lancet 1993 ; 341 : 837-8.

26) Morimoto K, Takeshita T. Low $\mathrm{Km}$ aldehyde Dehydrogenase (ALDH2) polymorphism, alcoholdrinking behavior, and chromosome alterations in peripheral lymphocytes. Environ. Health Perspect. $1996 ; 104: 563-7$.

27) Takeshita T, Mao X-Q, Morimoto K. The contribution of polymorphism in the alcohol dehydrogenase $\beta$-subunit to alcohol sensitivity in a Japanese population. Hum. Genet. 1996 ; 97 : 40913.

28) Takeshita T, Maruyama S, Morimoto K. Relevance of both daily hassles and the ALDH2 genotype to problem drinking among Japanese male workers. Alcohol. Clin. Exp. Res. 1998 ; 22 : 115-20.

29) Nakajima $M$, Morimoto $K$, et al. 8Hydroxydeoxyguanosine in human leukocyte DNA and daily health practice factors: Effects of individual alcohol sensitivity. Environ. Health Perspect. $1996 ; 104: 1336-8$.

30) Morimoto K. Social and Psycophysical Factors Correlated with the Quality of Life and Life Satisfaciton of the Elderly Living in Different Environments. In: Quality of Life in Aging Societies. Tokyo: Nihon University Population Research Institute, $1987: 135-6$.

31) 森本兼軖. ストレス科学ー集学的アプローチを目 指して一。加藤正明, 小泉明, 森本兼粪 (編)：ストレスと人間科学, 東京:広英社, $1987: 3-4$.

32) 森本兼粪. ライフスタイルから見る健康管理一ス トレスと精神的健康度を新しく評価する（その 1）-。労働衛生, $1988 ； 29,44-8$ 。

33) 森本兼粪. ライフスタイルとストレス評価. Current Laboratory Medicine 1991；9：29-36.

34) 森本兼軖, 夏目 誠, 川上憲人. ストレス測定. 河野友信, 吾郷晋浩（編）：ストレス診療ハンド ブック，東京：メディカル・サイエンス・イン夕
ーナショナル, $1990: 43-62$.

35) 森本兼粪. ライフスタイル環境と健康度との関連 性にかかわる予防医学的研究（第30回ベルツ賞受 賞論文), Deutsche Medizinische Wochenschrift 日本語翻訳版 $1994 ; 16: 50-66$.

36) 森本兼粪. ライフスタイルから見る健康管理一ス トレスと精神的健康度を新しく評価する（その 2 ）一。労㗢衛生 $1988 ； 29: 60-4$.

37) 森本兼軖. ライフスタイルと健康度評価ーリンパ 球染色体変異と免疫学的防御機構。病態生理 $1993 ; 12: 171-80$.

38) Ezoe S, Morimoto K. Quantitative assessment of stressors and stress reaction. A review. Jpn. J. Ind. Health 1994 ; 36 : 397-405.

39) Ezoe S, Morimoto K. Behavioral lifestyle and mental health status among Japanese industrial workers. Prev.Med. 1994 ; 23 : 98-105.

40) 森本兼粪. ストレス危機の予防医学. 東京：日本 放送出版協会, 1991 .

41) Morimoto K, et al. Proliferative kinetics of human lymphocytes in culture measured by autoradiography and sister chromatid differential staining. Exp. Cell Res. $1983 ; 145: 349-56$.

42) Takeuchi T, Nakajima M, Ohta Y, Mure K, Takeshita T, Morimoto K. Evaluation of 8hydroxydeoxyguanosine, a typical oxidative DNA damage, in human leukocytes. Carcinogenesis $1994 ; 15: 1519-23$.

43) Takeuchi T, Morimoto K. Increased formation of 8hydroxydeoxy- guanosine, and oxidative DNA damage, in lymphoblasts from Fanconi's anemia patients due to possible catalase deficiency. Carcinogenesis $1993 ; 14: 1115-20$.

44) Takeuchi T, Morimoto K, Kosaka H, Shiga T. Spin trapping of super oxide released by opsonized asbestos from human promyelocytic leukemia cell line, HL60. Biochem. Biophys. Res. Commun. $1993 ; 194: 57-64$.

45) Takeuchi T, Morimoto K. Crocidolite asbestos increased 8-hydroxyguanosine levels in cellular DNA of a human promyelocytic leukemia cell line, HL60. Carcinogenesis $1994 ; 15: 635-9$.

46) Takeuchi T, Nakajima $M$, Korimoto $K$. Establishment of a human system that generates $\mathrm{O}^{2}$ and induces 8-hydroxydeoxyguanosine, typical of oxidative DNA damage, by a tumor promoter. Cancer Res. 1994 ; 54 : 5837-40.

47) Takeuchi T, Nakajima M, Morimoto K. Calyculin A., a non- phorbolester type tumor promoter, induced oxidative DNA damage in stimulated human neutrophil-like cells. Biochem. Biophys. 
Res. Commun. 1994 ; 205 : 1803-7.

48) Tarumi K, Hagihara A, Morimoto K. An inquiry into the relationship between job strain and blood pressure in male white- collar workers. Jpn. J. Ind. Health $1993 ; 35: 269-76$.

49) 森本兼晒, 丸山総一郎. 生きがい感と健康. 環境
衛生 $1992: 10-4$.

50) 森本兼粪, 丸山総一郎, 江副智子. 老人のライフ スタイルとQOL。環境衛生1992：15-20.

51) 丸山総一郎, 森本兼襄. ライフスタイルと QOL QOL研究会 (編) : Quality of Life-QOLの目 指すもの一. 大阪：リプロ社, $1990 ; 129-86$. 